\title{
The Byers Basin: Jurassic-Cretaceous tectonic and depositional evolution of the forearc deposits of the South Shetland Islands and its implications for the northern Antarctic Peninsula
}

\author{
Joaquin Bastias $\mathbb{D}^{\mathrm{a}, \mathrm{b}}$, Mauricio Calderón ${ }^{c}$, Lea Israel ${ }^{\mathrm{a}}$, Francisco Hervéa,c ${ }^{\mathrm{a}}$, Richard Spikings ${ }^{\mathrm{b}}$, Robert Pankhurst ${ }^{\mathrm{d}}$, \\ Paula Castillo ${ }^{\mathrm{e}, \mathrm{f}}$, Mark Fanninge and Raúl Ugalde ${ }^{\mathrm{g}, \mathrm{h}}$ \\ ${ }^{a}$ Departamento de Geología, Universidad de Chile, Santiago, Chile; ${ }^{b}$ Earth Sciences Department, Université de Genève, Geneva, Switzerland; 'Carrera \\ de Geología, Universidad Andres Bello, Sazie 2119, Santiago, Chile; 'Visiting Research Associate, British Geological Survey, Keyworth Nottingham, UK; \\ eResearch School of Earth Sciences, Australian National University, Canberra Australia; fInstitut für Geologie und Paläontologie, Westfälische \\ Wilhelms-Universität Münster, Münster, Germany; ${ }^{9}$ Escuela de Geología, Facultad de Ciencias, Universidad Mayor, Providencia, Santiago, Chile; \\ hPEDECIBA Geociencias, Facultad de Ciencias, Universidad de la República, Iguí, Montevideo, Uruguay
}

\begin{abstract}
This paper addresses the Jurassic-Cretaceous stratigraphic evolution of fore-arc deposits exposed along the west coast of the northern Antarctic Peninsula. In the South Shetland Islands, Upper Jurassic deepmarine sediments are uncomformably overlain by a Lower Cretaceous volcaniclastic sequence that crops out on Livingston, Snow and Low islands. U-Pb zircon ages are presented for the upper Anchorage Formation $(153.1 \pm 1.7 \mathrm{Ma})$ and the Cape Wallace granodiorite of Low Island (137.1 $\pm 1.7 \mathrm{Ma})$ as well as ${ }^{40} \mathrm{Ar} /{ }^{39} \mathrm{Ar}$ ages of $136-139 \mathrm{Ma}$ for Low Island andesites. Data are also presented for a U-Pb age of 109.0 $\pm 1.4 \mathrm{Ma}$ for the upper volcanic succession of Snow Island. In combination with published stratigraphy, these data provide a refined chrono- and litho-stratigraphic framework for the deposits herein referred to as the Byers Basin. Tentative correlation is explored with previously described deposits on Adelaide and Alexander islands, which could suggest further continuation of the Byers Basin towards the south. We also discuss possible correlation of the Byers Basin with the Larsen Basin, a sequence that shows the evolution of foreland to back-arc deposits more or less contemporaneously with the fore-arc to intra-arc evolution of the Byers Basin.
\end{abstract}

ARTICLE HISTORY

Received 5 March 2019 Accepted 10 August 2019

KEYWORDS

Tectono-stratigraphical evolution; Weddell Sea; South Shetland Islands; Antarctic Peninsula; Jurassic cretaceous; basin evolution

\section{Introduction}

Mesozoic sedimentary and volcanic successions are widely exposed along the Pacific coastal areas of the Antarctic Peninsula (Figure 1). They exhibit geological evidence of both tectonic and global sea-level changes, notably recorded in the western flank of the northern Antarctic Peninsula by the emergence of submarine marginal basins as part of a continental island volcanic arc (e.g. Hathway and Lomas 1998; Riley et al. 2012) and the consequent proliferation of Cretaceous plant species (e.g. Philippe et al. 1995; Torres et al. 1997, 2015; Falcon-Lang and Cantrill 2001; Leppe et al. 2007). Relevant lithostratigraphic units and intrusive rocks are exposed in the archipelago of the South Shetland Islands and in southernmost Adelaide and Alexander islands (Figure 1, e.g. Hathway and Lomas 1998; Riley et al. 2012; Bastias and Hervé 2013). The potential correlation of these units in Antarctic Peninsula is crucial to understand the configuration of the tectonic processes occurring in the margin and possibly reveal insights of its evolution during the Mesozoic. However, there are significant uncertainties in the age of their igneous and sedimentary components.

In this study, we present the results of SHRIMP U-Pb analysis of magmatic zircons and ${ }^{40} \mathrm{Ar} /{ }^{39} \mathrm{Ar}$ analysis of volcanic groundmass from the main outcrop areas on Livingston, Snow Island and Low islands. The results are compared with data from previous work in the South Shetland Islands. The new geochronological data provide constraints for a discussion of fore-arc basin evolution along the north-west flank of Antarctic Peninsula and establish reference ages for the tectonic events and biostratigraphical evolution in similar basins on the Pacific coast of the central and southern Antarctic Peninsula.

\section{Geological framework}

The Late Jurassic to Early Cretaceous evolution of the convergent margin of Antarctic Peninsula was preceded by its separation from Gondwana during the earliest Jurassic opening of the Weddell Sea (e.g. König and Jokat 2006) and the development of the Larsen basin (e.g. Hathway

CONTACT Joaquin Bastias j.bastias.silva@gmail.com Departamento de Geología, Universidad de Chile, Plaza Ercilla 803, Santiago, Chile

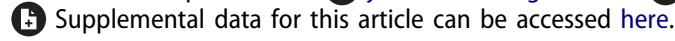




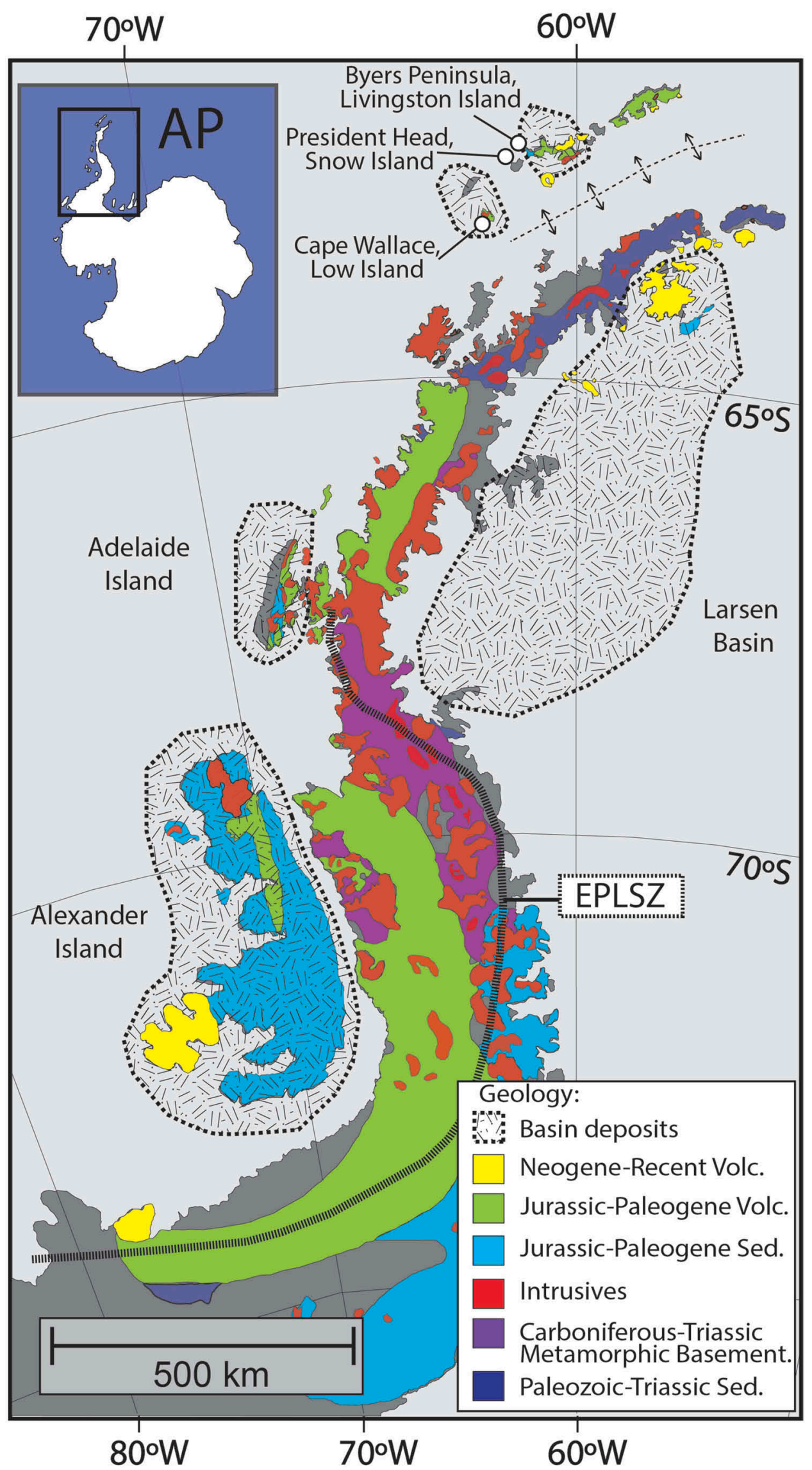

Figure 1. Geological map of the Antarctic Peninsula showing the distribution of the principal geological units, modified from Burton-Johnson and Riley (2015). The islands of Livingston, Snow, Low, Adelaide and Alexander are indicated by shaded areas with black dotted perimeter. AP, Antarctic Peninsula; EPLSZ, Eastern Palmer Land Shear Zone (from Vaughan and Storey 2000). Larsen Basin is demarked (Del Valle et al. 1992; Hathway 2000). 
2000), whose sedimentary fill is exposed along the eastern flank of the peninsula (Figure 1). The pre-Cretaceous geology of the northwestern Antarctic Peninsula comprises Permian-Triassic metaturbidites of the Trinity Peninsula Group (e.g. Castillo et al. 2015), Jurassic silicic volcanic rocks (Pankhurst et al. 2000; Riley et al. 2001) and Middle and Late Jurassic granites of the Antarctic Peninsula batholith (Pankhurst 1982; Leat et al. 1995). Upper JurassicLower Cretaceous stratigraphy is well preserved as sedimentary, volcanic and volcaniclastic successions of the Byers Group at Byers Peninsula, Livingston Island (e.g. Hathway and Lomas 1998), at President Head on Snow Island (e.g. Duane 1996; Torres et al. 1997; Israel 2015) and at Cape Wallace on Low Island (e.g. Bastias, 2014; Smellie et al. 1984). The published stratigraphy of these rocks is summarized below in this Section. Further south, on Adelaide and Alexander islands (Figure 1), similar rocks are exposed that will also be considered to assess possible correlation with the units of the Byers Basin.

\subsection{Stratigraphy of the Byers group}

The type localities of the Byers Group (Hathway and Lomas 1998) are exposed at Byers Peninsula, Livingston Island
(Figure 2). The base and the top of the group are not exposed, but overall thickness is estimated to be at least $2.7 \mathrm{~km}$. Contact relations between the formations are locally obscured by high-angle faults, folding and of younger hypabyssal and plutonic intrusions (e.g. Hathway and Lomas 1998); others are covered by the ice cap.

The Upper Jurassic-Lower Cretaceous succession of the Byers Group has been interpreted as a regressive mega-sequence (Lomas 1999) of marine to continental sedimentary intra-arc facies (Smellie et al. 1980; Hathway 1997), controlled by tectonism and volcanism associated with subduction of the Farallon Plate rather than eustatic sea-level changes (Hathway and Lomas 1998). Alternatively, it has been interpreted as a succession deposited in a marginal ante-arc basin (Crame et al. 1993).

Hathway (1997) and Hathway and Lomas (1998) reviewed the Byers Group lithostratigraphy originally proposed by Smellie et al. (1980) and Crame et al. (1993). At the base, the Anchorage Formation consists of radiolarian-rich hemipelagic mudstones deposited in a deep-marine environment of Kimmeridgian-Tithonian age (Figure 3, ca. 157-145 Ma). It is succeeded by Berriasian (Figure 3, ca. 145-140 Ma) terrigenous slope-apron mudstones and sandstones of the President Beaches Formation, overlain

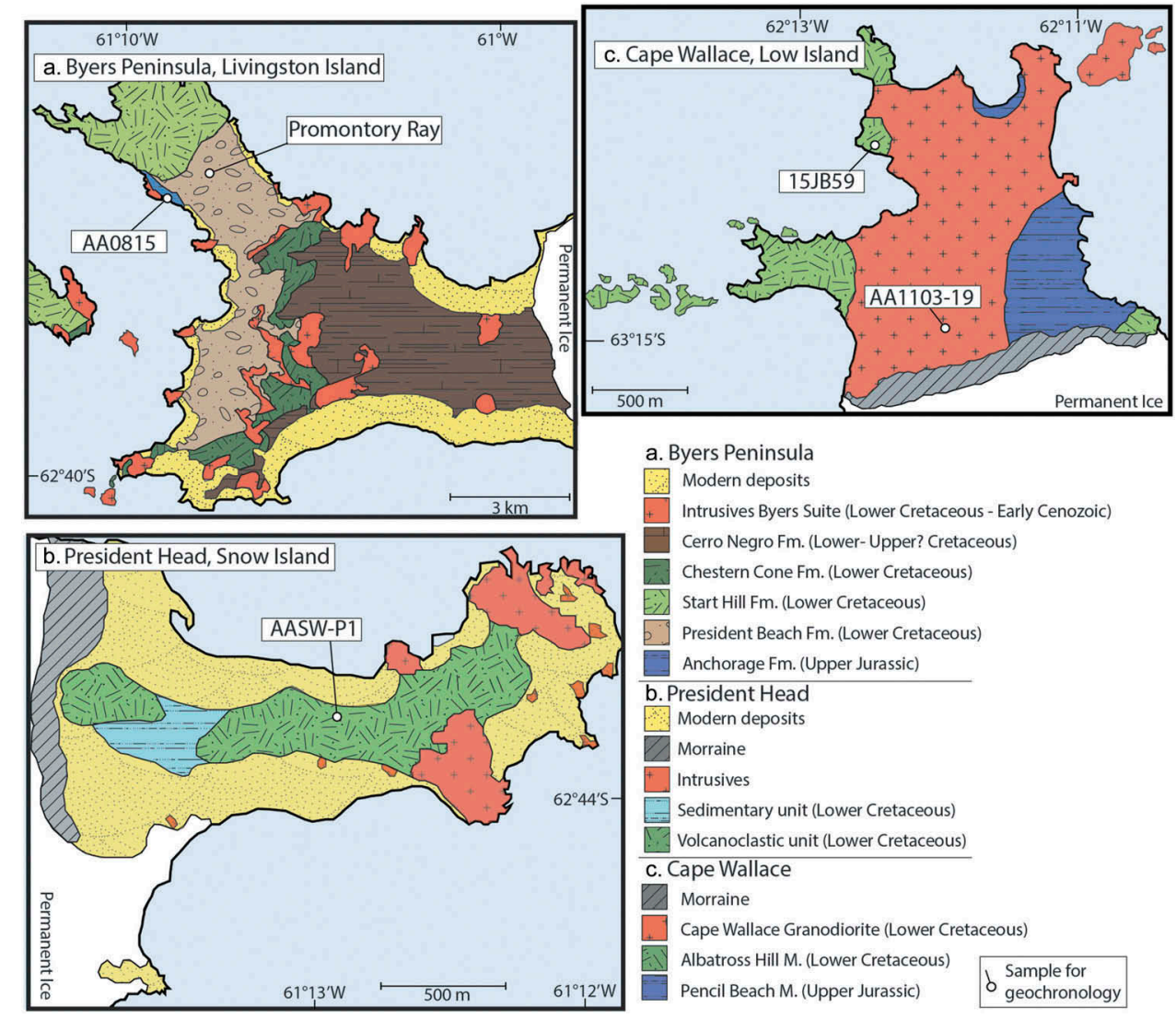

Figure 2. Revised geological map of the Byers Basin deposits. (a) Byers Peninsula, Livingston Island, modified from Hathway and Lomas (1998), (b) President Head Peninsula, Snow Island, modified from Israel (2015), (c) Cape Wallace, Low Island, modified from Bastias (2014). 


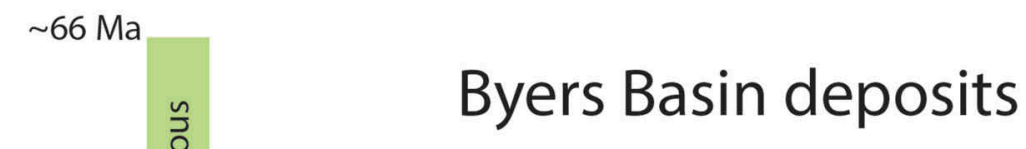

\section{Byers Basin deposits}

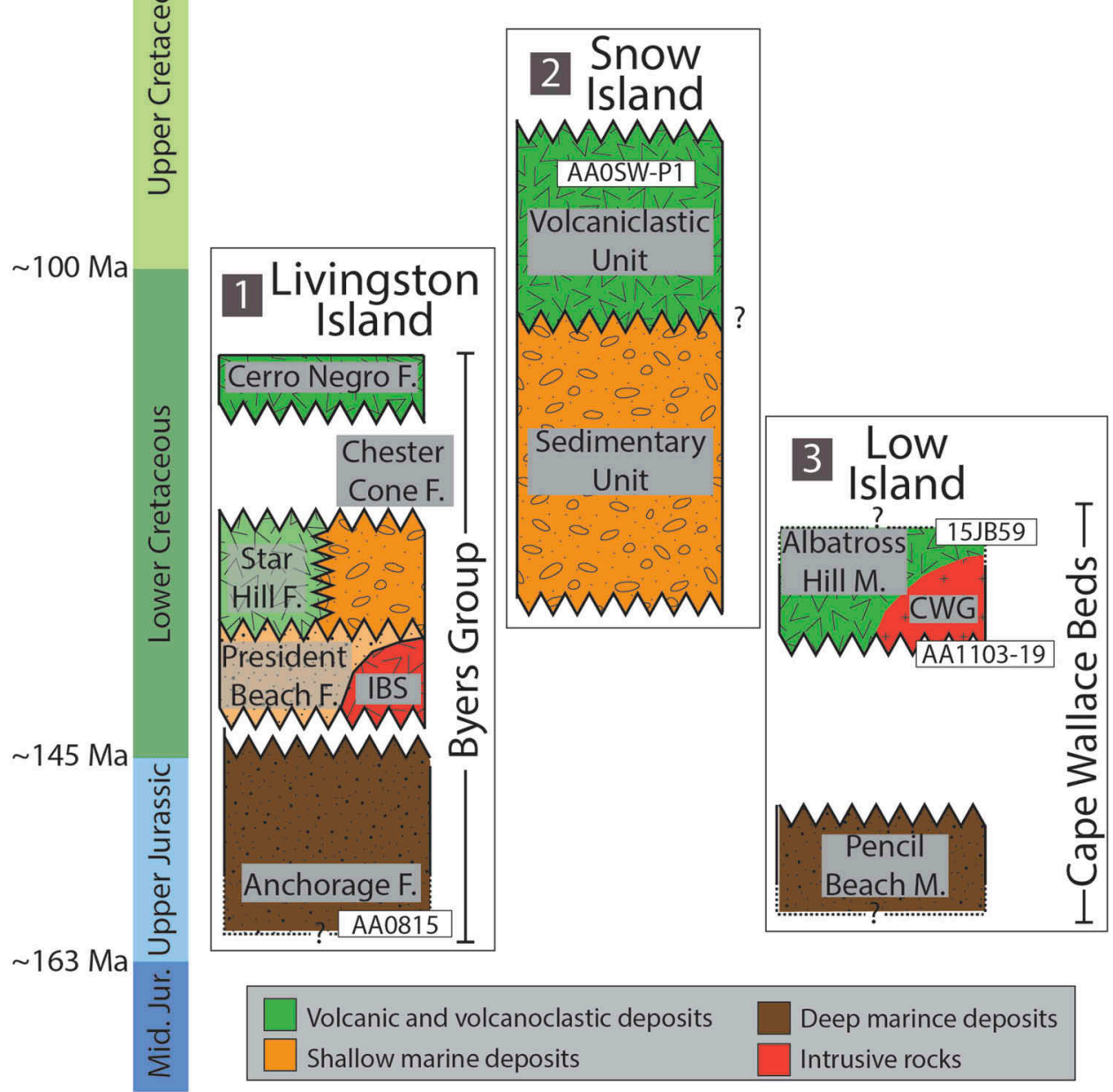

Figure 3. Schematic comparative stratigraphy of the fore-arc deposits here proposed to be considered as part of the Byers Basin. North to south are: the Byers Group of Livingston Island (from Hathway and Lomas 1998, Kiessling et al., 1999); Snow Island (from Israel Israel 2015) and the Cape Wallace Beds of Low Island (from Bastias, 2014). IBS, Intrusive Byers Suite; CWG, Cape Wallace Granodiorite.

in turn by Berriasian-Valanginian (Figure 3, ca. 145-133 Ma) shallower-marine conglomerates and mudstones of the Chester Cone Formation and volcanic breccias of the Start Hill Formation, which are interpreted as the debris-apron flank of a volcanic edifice. A Valanginian-Aptian erosional hiatus (Figure 3, ca. 140-120 Ma) was followed by deposition of Aptian subaerial and non-marine volcaniclastic rocks of the Cerro Negro Formation (Figure 3).

\subsubsection{Anchorage formation (kimmeridgian - early Berriasian)}

This formation was first defined by Crame et al. (1993) and is equivalent to part of the Byers Formation of Valenzuela (1971) and the fangolite member of Smellie et al. (1980). Its outcrops are confined to an area of $0.5 \mathrm{~km}^{2}$ in the northwest sector of Byers Peninsula
(Figure 2), where they form a homoclinal succession dipping to the north-west and are intruded by tabular microdioritic bodies. Hathway and Lomas (1998) separate it into the New Plymouth and Punta Ocoa members, which reach a combined thickness of about $120 \mathrm{~m}$. The members are lithologically distinguishable and differ markedly in the degree of bioturbation. The contact between them is uncertain, since they are separated by a high-angle NW-SE trending fault.

The New Plymouth Member consists of mudstones that exhibit notable bioturbation and numerous silicic tuff layers, with normally graded well-defined bases locally bioturbated by Chondrites isp. Scarce but thick, turbiditic sandstones represent Tabc Bouma horizons. This member is in contact through a near-vertical fault with the President Beaches Formation. 
The Punta Ocoa Member is mainly composed of radiolarian-rich shales, with volcanic ash tuff layers, fine layers of massive sandstone and thicker ones interpreted as Tabc Bouma horizons with mudstone intraclasts (Pirrie and Crame 1995; Hathway and Lomas 1998).

The Anchorage Formation contains abundant belemnites (Belemnopsis stolleyi Stevens and Hibolithes marwicki marwicki Stevens; Smellie et al. 1980), bivalves (inoceramids such as Retroceradamus haasti Hochstetter; Crame 1984), ammonites (Smellie et al. 1980; Kiessling et al., 1999), radiolarians (Kiessling et al. 1999) and wood remains and leaves. The fossil record suggests a Kimmeridgian - early Berriasian age (Kiessling et al. 1999). Smellie et al. (1984) noted an (unpublished) $\mathrm{Rb}-\mathrm{Sr}$ whore-rock isochron age for mudstones of $163 \pm 4 \mathrm{Ma}$, which could suggest some deposition as old as Oxfordian. The mudstones can be mostly interpreted as deep hemipelagic deposits but some have been deposited by weak turbidity currents. The sandstones and some tuffs are interpreted as turbidites (Pirrie and Crame 1995) and show a limited volcaniclastic input from the Late Jurassic magmatic arc. The New Plymouth and the Punta Ocoa members show evidence of deposition under aerobic and anaerobic-dysaerobic conditions, respectively.

\subsubsection{President beaches formation (Berriasian)}

This was defined by Crame et al. (1993) and redefined by Hathway and Lomas (1998), who delimit a typical area extending 0.5 to $1.5 \mathrm{~km}$ inland from President Beaches Peninsula and estimate a thickness of at least $600 \mathrm{~m}$. It is considered equivalent to part of the Byers Formation of Valenzuela Ayala (1971) and to part of the mixed marine member of Smellie et al. (1980). It overlies the Anchorage Formation in apparent unconformity. It is overlain with abrupt contact by conglomerate beds of the Chester Cone Formation and, in apparent discordance, by the Start Hill Formation.

The President Beaches Formation consists mainly of dark grey shales with pyrite, radiolarians and isolated trace fossils. It is characterized by yellowish clay-rich strata $0.5-4 \mathrm{~cm}$ thick (interpreted as altered tuffs), layers of grey-green sandstones and centimetric carbonate concretions. There are also lenticular bodies of sandstone of greater thickness $(8-45 \mathrm{~m})$ with small-scale syn-sedimentary deformation (load traces, flame structures, convolute lamination, clastic dykes) caused by a submarine relief and high sedimentation rates (Lomas 1999).

Hathway and Lomas (1998) proposed that the President Beach Formation was probably deposited in a submarine slope fan below the base level of storm waves, where mud deposition was sporadic and locally interrupted by sandy turbidite flows confined to small channels. The material might have come from a volcanic arc with vegetation, located to the southeast (Lomas 1999). The rocks contain macrofossils of Berriasian affinity, including ammonites (Spiticeras, Blanfordiceras, Himalayites, Bochianites; Smellie et al. 1980), bivalves (Manticula Waterhouse, Praeaucellina, Inoceramus; Crame et al. 1993) and belemnites (Smellie et al. 1980; Crame et al. 1993; Pirrie and Crame 1995). Duane $(1994,1996)$ further described the presence of dinoflagellate assemblages that would indicate a mid-to-late Berriasian age.

\subsubsection{Start hill formation (Berriasian - Valanginian)}

This was defined as a formation by Hathway and Lomas (1998); it is equivalent to the Start Formation of Valenzuela Ayala (1971) and the agglomerate member of Smellie et al. (1980). The stratotype exposures are located in the northern half of Ray Promontory (Figure 2). The thickness is estimated to be at least $265 \mathrm{~m}$. The top is unknown, while its base is well defined, in apparently discordant contact with the mudstones of the President Beaches Formation (Valenzuela and Hervé 1972; Smellie et al. 1980).

The formation is mainly composed of massive, poorly sorted volcanic breccias and both clast- and matrix-supported conglomerates that form very thick strata $(5-30 \mathrm{~m})$. The clasts, mostly smaller than $30 \mathrm{~cm}$ but up to $3 \mathrm{~m}$ in diameter and generally angular, are of basalt and basaltic andesite with porphyritic and amygdaloidal texture. The contacts between strata are mainly gradational with pronounced lateral variation. There are geographically restricted volcanic agglomerates of grey and brown, finely laminated, lapilli tuffs and lavas.

Given the presence of a molluscan assemblage, dominated by oyster shell fragments (Smellie et al. 1980), this formation has been interpreted as part of a fan of submarine debris that surrounded one or more basaltic subaerial volcanoes. The contact relationship with the Chester Cone Formation is unknown. Hathway and Lomas (1998) assigned a Berriasian age, while Haase et al. (2012) suggested Valanginian based on ${ }^{40} \mathrm{Ar} /{ }^{39} \mathrm{Ar}$ dating of aphyric lavas $(135.2 \pm 2.6 \mathrm{Ma})$.

\subsubsection{Chester cone formation (late Berriasian - early Valanginian)}

This formation was defined by Crame et al. (1993) and redefined by Hathway and Lomas (1998), who divided it into two members: the basal Devils Point Member, previously included at the top of the Anchorage Formation by Crame et al. (1993), and the Sealer Hill Member at the top. 
The type locality of the Devils Point Member is wedge-shaped with an estimated thickness of $300 \mathrm{~m}$ and has been affected by numerous faults. It apparently overlies the President Beaches Formation with very low-angle unconformity (Hathway and Lomas 1998). The lower part is composed of pebble conglomerates, matrix- to clast-supported, of mottled appearance and grey-orange colour, with well-rounded clasts of basaltic to intermediate volcanic rocks and beige-grey mudstone intraclasts. The beds have very marked erosive bases, where sandstone horizons and dark grey shales overlap each other. The upper part consists of conglomerates of gravel and thick greyish sandstones with fossil remains. Some of the sandstones are interpreted as turbidites with Tbc Bouma divisions. The fossil content is dominated by thick-shelled bivalves that appear to be reworked (Crame et al. 1993), probably by turbidity currents that remobilized coastal gravels (Duane 1996). The Devils Point member is intruded by the Chester Cone andesite plug, for which Pankhurst et al. (1979) obtained a Valanginian K-Ar amphibole age of $132 \pm 4$ Ma.

The Sealer Hill Member reaches about $56 \mathrm{~m}$ thick with general dip of $30^{\circ} \mathrm{NE}$. Contact with the Devils Point Member is gradational and it is unconformably overlain by the Cerro Negro Formation (Crame et al. 1993; Hathway 1997; Hathway and Lomas 1998). It consists of dark, finely laminated, fairly bioturbated shales, millimetric to centimetric layers of fine-grained graded sandstone that sometimes reach greater thicknesses and exhibit parallel to wavy lowangle stratification, and scarce one-metre thick strata of massive and poorly selected conglomerates, with pebblesize basaltic clasts in a gravel-to-sand matrix. The shales might be low-energy suspension deposits while sandstones and conglomerates might be the product of storm deposits (Hathway and Lomas 1998). There are also levels with carbonate concretions, and calcite veins up to $2.5 \mathrm{~cm}$ thick. An ammonite assemblage with species of Bochianites, Uhligites and Neocomites, indicates a Valanginian age (Covacevich 1976), with belemnites (Belemnopsis (Belemnopsis) alexandri Willey and B.(B.) gladiatoris Willey (Crame et al. 1993), plants and bivalves. Duane (1996), by means of palynology, defined the maximum age as Valanginian.

\subsubsection{Cerro negro formation (early aptian - campanian?)}

The Cerro Negro Formation (Hathway 1997) encompasses all the continental volcaniclastic strata exposed on the eastern side of Byers Peninsula: it is equivalent to the Cerro Negro Formation of Valenzuela Ayala (1971) and to the volcanic member of Smellie et al. (1980). It has an approximate thickness of $1.4 \mathrm{~km}$, measured in a composite type section, and dips gently to the ENE. It overlies in low-angle unconformity both members of the Chester Cone Formation and in places overlaps onto the President Beaches Formation. The top is hidden under the present ice cap.

Hathway (1997) informally divided the Cerro Negro Formation into two members separated by an abrupt and striking colour change, which may represent a diagenetic limit rather than a stratigraphic one. The first member consists of 200 to $240 \mathrm{~m}$ of silicic volcaniclastic rocks of pale green to grey colour (weathering effect), and silicic welded or non-welded ignimbrites intercalated with reworked and silicic pyroclastic material. The second member, mostly syn-eruptive and of dark red-purple colour (due to the predominance of basaltic rocks) is composed of lapilli tuffs and tuff breccias, interpreted as debris flows and flood flows, respectively. Two welded silicic ignimbrites rich in basaltic clasts represent the volcanic material at the foot of stratovolcanoes (Hathway 1997). The formation also includes basaltic conglomerates deposited in fluvial channels, smaller intervals of lacustrine deposits and paleo-sols that have been associated with inter-eruptive facies. Changes in thickness and facies support a synsedimentary displacement along normal and southvergent ENE-trending faults (Hathway 1997).

These rocks contain abundant macro- and micro- fossil vegetation of various groups: Cycadeoidophyta, Pteridophyte, Prespermatophyta, Coniferophyta, Cycadophyta and Arthrophyta, corresponding to a late Aptian age (Duane 1996; Torres et al. 1997; Cantrill 2000). ${ }^{40} \mathrm{Ar} /{ }^{39} \mathrm{Ar}$ analysis of plagioclase from a basal tuff yielded an age of $120.3 \pm 2.2 \mathrm{Ma}$ (Hathway 1997; Hathway et al. 1999). Ignimbritic clasts in a conglomerate unit $140 \mathrm{~m}$ below the top of the succession yielded ${ }^{40} \mathrm{Ar} /{ }^{39} \mathrm{Ar}$ ages of $119.4 \pm 0.6$ $\mathrm{Ma}$ and $119.1 \pm 0.8 \mathrm{Ma}$ on biotite and plagioclase, respectively (Hathway et al. 1999), suggesting fast deposition during the latest Aptian. Many younger K-Ar ages have been obtained from the upper part of the Cerro Negro Formation including the intrusive rocks at Negro Hill, ranging from ca. $110 \mathrm{Ma}$ to ca. $80 \mathrm{Ma}$ (Pankhurst et al. 1979; Smellie et al. 1984).

Some authors consider the possibility of placing the Cerro Negro Formation in a stratigraphic framework outside the Byers Group, denoting the current status as provisional (Hathway 1997; Hathway and Lomas 1998). Considering the international stratigraphic conventions, we will retain the unit in the Byers Group.

\subsection{Geology of president head peninsula, snow island}

The outcrops of Snow Island are mostly restricted to President Head Peninsula, $\sim 10 \mathrm{~km}$ south of Byers 
Peninsula (Figure 2). Due to their proximity and based on litho-, bio- and tectono-stratigraphic similarities, Crame et al. (1993) suggested correlations between these rocks and the Byers Group (Figure 3).

Several authors have suggested that the marine ammonite-bearing sedimentary succession at the western end of President Head could be correlated with the Sealer Hill Member of the Chester Cone Formation (Crame et al. 1993; Torres et al. 1997; Hathway and Lomas 1998; Israel et al., 2015). Furthermore, the pattern of the Chester Cone Formation of maroon-weathering mudstones at the base, interbedded with normally graded, medium-grained sandstones (e.g. Smellie et al. 1984; Crame et al. 1993) is also found in the western area of Snow Island (Israel 2015). The occurrence of Valanginian ammonites is also a common element between both localities. Two taxa were reported from Snow Island: Aulacosphinctes cf. proximus (Steuer) (Ugalde et al. 2013) and Olcostephanus? cf. atherstoni (Sharpe) (Israel 2015), the latter constraining the depositional age to the mid-Valanginian.

\subsection{Geology of cape wallace (low island)}

Cape Wallace lies at the northwestern end of Low Island (Figure 2), practically the only part not covered by the ice cap, exposing about $4 \mathrm{~km}^{2}$ of rock outcrops. The rocks consist of a fine-grained sedimentary unit overlain by a volcanic succession, both intruded by a granodiorite pluton (Bastias, 2014; Araya and Hervé 1966; Smellie 1979).

Smellie (1979) first described the bedded sequence at Low Island, later redefined by Bastias and Hervé (2013) as the Cape Wallace Beds. In this study, we propose two members, the Pencil Beach and the Albatross Hill, which are equivalent to the 'sedimentary member' and 'volcanic member' defined by Smellie (1979), respectively (Figure 3).

Outcrops of the Pencil Beach Member are located in the southeast and the northeast parts of Cape Wallace (Figure 2). These strata are well bedded and include fine-grained volcaniclastic claystones, crystal tuffs and lapillistones (Figure 4). Individual beds are generally 4-30 cm thick, laterally uniform and continuous, and have been interpreted as turbiditic deposits (Smellie et al. 1984). Primary sedimentary structures are uncommon, except for some cross-lamination, disrupted beds, and graded bedding that is frequently observed in thin section (Smellie 1979). The strata strike between NW-SE and $\mathrm{E}-\mathrm{W}$, with a dip varying from sub-horizontal to $30^{\circ} \mathrm{N}$. Thomson (1982) reported in-situ trace and molluscan fossils that suggest a Late Jurassic age, and an ammonite identified as Epimayites aff. transiens (Waagen), corresponding to late Oxfordian.
The Albatross Hill Member unconformably overlies the Pencil Beach Member and consists of a succession of subaerial lava flows. Lavas and hyaloclastites are aphyric or feldspar-phyric augite-andesites, hornblende-andesites and rare basalts (Smellie 1979). Both lithostratigraphic units are intruded by the Cape Wallace pluton (Bastias, 2014; Smellie 1979), a granodiorite from which Smellie et al. (1984) obtained a whole-rock K-Ar age of $120 \pm 4 \mathrm{Ma}$.

\section{Samples and analytical methods}

\subsection{U-pb zircon geochronology}

Three samples were selected for U-Pb zircon dating. AA0815 is from a fine-grained volcanic ash layer interbedded within the Punta Ocoa Member of the Anchorage Formation at Ray Promontory (Figures 2 and 4), northwestern Byers Peninsula, Livingston Island. AA1103-19 is granodiorite from the Cape Wallace pluton in south-central Cape Wallace, Low Island (Figures 2 and 4). This is a medium- to coarse-grained phaneritic rock $(2-5 \mathrm{~mm})$ composed of subhedral plagioclase (50\%), anhedral quartz (38\%), subhedral orthoclase (7\%), and subhedral amphibole (hornblende type; $3 \%$ ). Alteration of plagioclase is intense but more moderate in orthoclase and hornblende. Secondary assemblages include albite, actinolite, minor chlorite and titanite, and clays. AASW-P1 is fine-grained greyish tuff from President Head, Snow Island (Figure 2).

Zircon was separated at the Research School of Earth Sciences, ANU, using standard crushing, hydraulic, magnetic and heavy liquid procedures. Several hundred randomly poured grains from each sample were cast in epoxy mounts together with the Temora reference zircon and polished to about halfway through the grains. The grains were photographed under an optical microscope using transmitted and reflected light, and their internal structure was $\mathrm{CL}$ imaged using a Scanning Electron Microscope (SEM). U-Pb isotopic compositions were measured using SHRIMP II and SHRIMP RG ion microprobes, following standard procedures (see Williams 1998 and references therein). For two samples igneous crystallization ages were determined from 10 to 15 grains with particular attention paid to ensure analysis of areas free of inclusions and fractures. $\mathrm{An}_{2}^{-}$primary ion beam was focused to a spot of $\sim 20 \mu \mathrm{m}$ diameter and each analysis consisted of the measurement of five cycles through the isotope mass sequence. $\mathrm{U} / \mathrm{Pb}$ ratios were determined by reference to Temora $\left({ }^{206} \mathrm{~Pb} /{ }^{238} \mathrm{U}=0.06683\right.$ equivalent to $417 \mathrm{Ma}$, Black et al. 2003) and $U$ concentrations are relative to analyses of SL13 $(\mathrm{U}=238 \mathrm{ppm})$. The data were processed using the SQUID Excel Macro (Ludwig 2001); calculations and plots were done using ISOPLOT (Ludwig 2003) and 


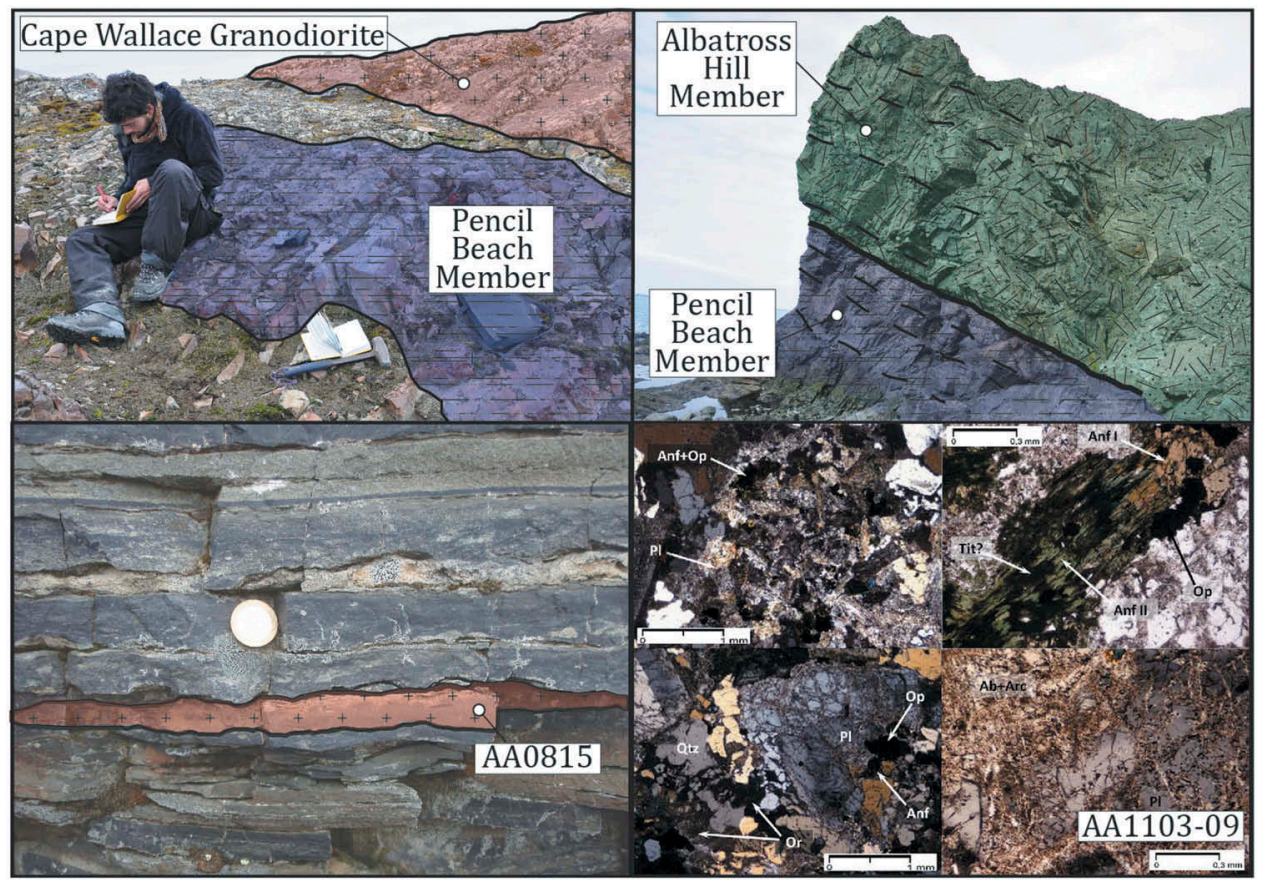

Figure 4. Fieldwork and petrography. At the top fieldwork photos showing the units of the Cape Wallace Beds. At the bottom: left the outcrop showing the sample for geochronology AA0815 and to the right the petrography of the sample AA1103-09: a hornblende granodiorite. All the material collected from the samples AA0815 and AASW-P1 was used to obtain the zircon concentrates for the U-Pb geochronology, thus it was not possible to perform petrographical studies in those samples. Anf, amphibole; Op, opaque; PI, plagioclase; Tit, titanite; Or, orthoclase; Qtz, quartz; Ab, albite.

DensityPlotter (Vermeesch 2012). Results are presented in Supplementary Table 1-3 and Figure 5.

\section{$3.3^{40} \mathrm{Ar} /{ }^{39} \mathrm{Ar}$ analysis}

Two samples from the Albatross Hill Member of the Cape Wallace Beds, Low Island (Figure 2) were used for whole-rock ${ }^{40} \mathrm{Ar} /{ }^{39} \mathrm{Ar}$ dating. $15 \mathrm{JB} 59$ is of andesitic lava with pyroclastic and dioritic fragments from central-north Cape Wallace. Porphyritic texture is dominant in the groundmass. Primary minerals are mainly plagioclase, amphibole and olivine that are partially altered to clays. $15 \mathrm{JB} 60$ is from another andesitic lava nearby with hypocrystalline to porphyritic texture: the phenocrysts are olivine.

${ }^{40} \mathrm{Ar} /{ }^{39} \mathrm{Ar}$ analyses were performed in the Noble Gas Laboratory of the University of Geneva. Handpicked unaltered mafic groundmass was concentrated and then separated by magnetic susceptibility (magnetic under $2.5 \mathrm{~V}$ and between under $5 \mathrm{~V}$ ) and rinsed in deionized water and $5 \% \mathrm{HNO}_{3}$ in an ultrasonic bath, packed in copper foil and irradiated the Oregon State University nuclear reactor with the Fish Canyon Tuff sanidine used as a fluence monitor (with an age 28.20 $\pm 0.16 \mathrm{Ma}$, Kniper et al. 2008). Since there is no reference of the age of the volcanic rocks of Low Island, each sample was irradiated in duplicate for different times to ensure optimum yields. Samples were degassed by $\mathrm{CO}_{2}-\mathrm{IR}$ laser step-heating, and the extracted gas was gettered in a stainless steel UHV line, after passing through a cold trap chilled to $\sim 150^{\circ}$ K. Argon isotopes were analysed using a GV Instruments Argus mass spectrometer equipped with four high-gain $\left(10^{12}\right.$ ohms) Faraday detectors and a single $10^{11} \mathrm{ohm}$ Faraday detector $\left({ }^{40} \mathrm{Ar}\right)$. Data reduction was performed using ArArCalc software (Koppers 2002). Ages were calculated using the ${ }^{40} \mathrm{~K}$ decay constant from Steiger and Jager (1977). Peak heights and blanks were corrected for mass discrimination, isotopic decay of ${ }^{39} \mathrm{Ar}$ and ${ }^{37} \mathrm{Ar}$ and interfering nucleogenic $\mathrm{Ca}$-, $\mathrm{K}-$, and $\mathrm{Cl}$-derived isotopes. Age plateaux were determined using the criteria of Lanphere and Dalrymple (1978). The results are presented in Figure 6 and further information in the supplementary material (Supplementary Table 4).

\section{Results}

\subsection{Zircon u-pb ages}

Zircons from the tuff sample AA0815 (Anchorage Formation, Livingston Island) are euhedral and subhedral crystals with no clear evidence of inherited features. Eleven analyses yielded coherent ages of 

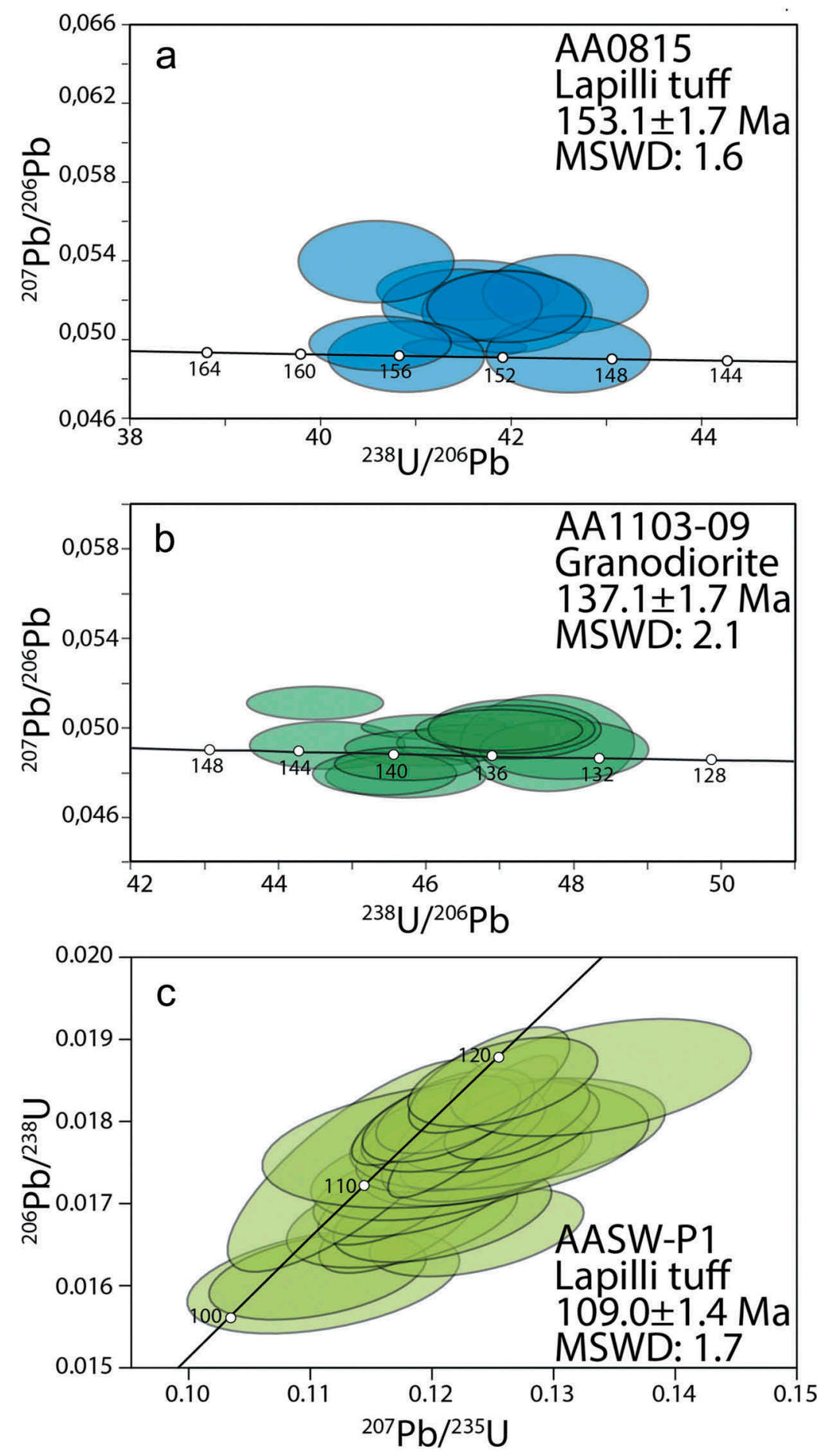

Figure 5. U-Pb zircon geochronology Tera-Wasserburg diagrams. At the top, the sample AA0815 an ash-layer at anchorage formation, livingston Island. At the middle the sample AA1103-19, a granodiorite from Cape Wallace Granodiorite, Low Island. At the bottom, the sample AAOSW-P1, an ash-layer at the volcanoclastic unit at President Head, Snow Island, plotted in a Wetherill Concordia diagram. All three ages are weighted mean ${ }^{206} \mathrm{~Pb} /{ }^{238} \mathrm{U}$ ages with $2 \sigma$ uncertainties.

149-157 Ma, with a concordant ${ }^{206} \mathrm{~Pb} /{ }^{238} \mathrm{U}$ weighted mean of $153.1 \pm 1.7 \mathrm{Ma}$ with an MSWD of $1.6(95 \%$ confidence level including reproducibility of the standard). The MSWD is 1.6 , and the result is considered to date crystallization of the tuff (Figure 5(a)).
Zircons from granodiorite sample AA11-03-19 (Cape Wallace) are euhedral and subhedral crystals. Most have very high $U$ and Th contents (>1000 ppm). Fifteen grains were analysed yielding a concordant ${ }^{206} \mathrm{~Pb} /{ }^{238} \mathrm{U}$ ages of $134-143 \mathrm{Ma}$, slightly outside 

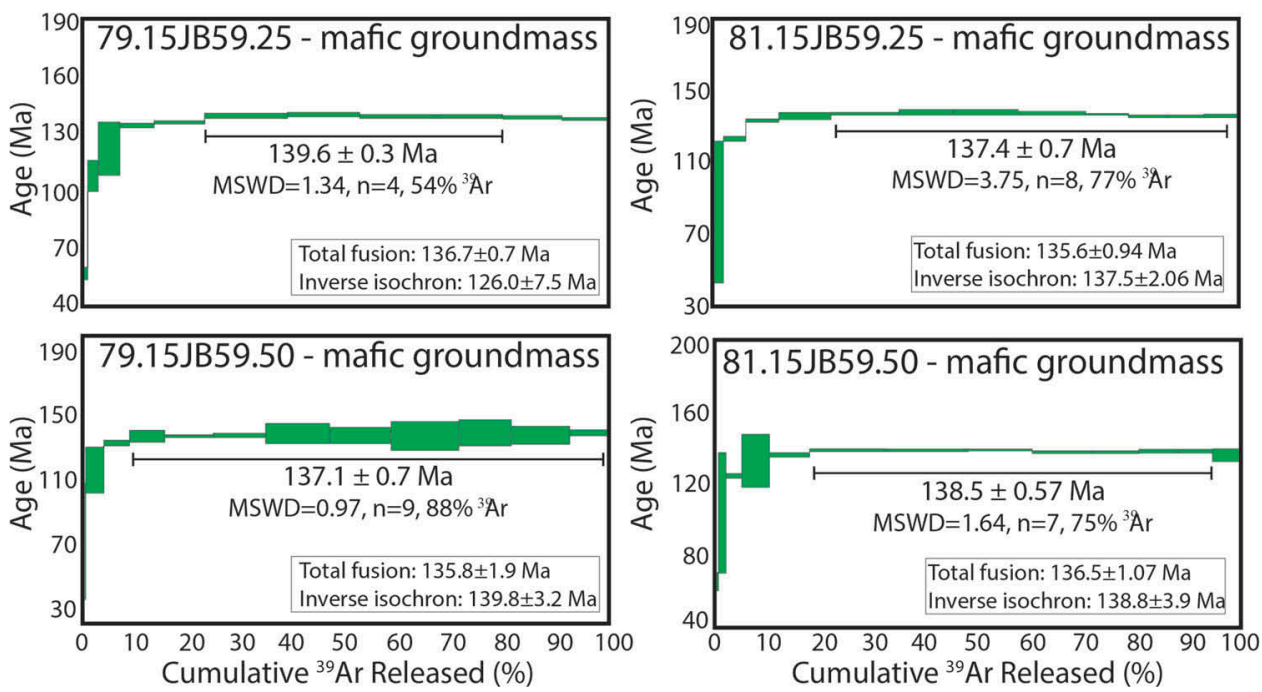

Figure $6 .{ }^{40} \mathrm{Ar} /{ }^{39} \mathrm{Ar}$ age spectra (plateau ages) of mafic groundmass from Albatross Hill member of the Cape Wallace Beds at low Island. All uncertainties are $\pm 2 \sigma$.

analytical uncertainty. If the two oldest ages are omitted, the remaining 13 give a weighted mean of $137.1 \pm 1.7$ Ma with an MSWD of 1.7 (Figure 5(b)). This is considered to date intrusion of the Cape Wallace pluton more accurately than the K-Ar ages of $121 \pm 3$ Ma (whole-rock) and $120 \pm 4 \mathrm{Ma}$ (hornblende) reported by Smellie et al. (1984).

The sample AASW-P1 corresponds to an ash-layer that contain euhedral and subhedral crystals. Sixteen grains were analysed yielding a concordant ${ }^{206} \mathrm{~Pb} /{ }^{238} \mathrm{U}$ weighted mean age of $109.0 \pm 1.4 \mathrm{Ma}$, with an MSWD of 1.7 (Figure 5(c)).

\section{$4.2{ }^{40}$ ar/ $^{39}$ ar ages}

${ }^{40} \mathrm{Ar} /{ }^{39} \mathrm{Ar}$ age spectra and inverse isochrons acquired in mafic groundmass from the volcanic unit in Low Island are shown in Figure 6 with all errors reported at the 20level. All initial interpolated ${ }^{40} \mathrm{Ar} /{ }^{36} \mathrm{Ar}$ ratios overlap with the atmospheric value of 295.5 (Steiger and Jager 1977). The samples yielded plateau ages according to the definition of Lanphere and Dalrymple (1978), despite of the widespread presence of alteration minerals in the volcanic rocks of mafic composition in the archipelago (Bastias et al. 2016).

Mafic groundmass from the sample 79.15JB59.25 yielded an ${ }^{40} \mathrm{Ar} /{ }^{39} \mathrm{Ar}$ plateau age of $139.7 \pm 0.3 \mathrm{Ma}(55 \%$ of ${ }^{39} \mathrm{Ar}$ released) compared to a total fusion age of $137 \pm$ 0.7 Ma. The low-temperatures' steps record a 'stair-case' age spectrum increasing from $\sim 40 \mathrm{Ma}$ to $\sim 120 \mathrm{Ma}$, which we tentatively interpret as consequence of Ar loss during either slow cooling or post-crystallization reheating. A similar age pattern was obtained from the duplicate analysis $81.15 \mathrm{JB} 59.25$, with a ${ }^{40} \mathrm{Ar} /{ }^{39} \mathrm{Ar}$ mean weighted plateau ages of $137.5 \pm 0.7 \mathrm{Ma}\left(75 \%\right.$ of ${ }^{39} \mathrm{Ar}$ released) and a total fusion age of $135.7 \pm 0.9 \mathrm{Ma}$. Duplicate analyses of the second sample (79.15JB59.50 and 81.15JB59.50) gave similar plateau ages $137.1 \pm 0.7 \mathrm{Ma}$ (85\% of ${ }^{39} \mathrm{Ar}$ released) and $138.5 \pm 0.6 \mathrm{Ma}\left(80 \%\right.$ of ${ }^{39} \mathrm{Ar}$ released). The duplicate plateau ages do not overlap within analytical error (for either sample): in contrast, the four total fusion ages give a robust weighted mean of $136.4 \pm 0.5 \mathrm{Ma}$ (MSWD = 1.2). The best estimate of the eruptive age of the andesites is considered to be in the interval encompassed by the four plateau ages, i.e. 137-140 Ma (early Valanginian).

\section{Discussion}

\subsection{The byers group and the possible correlations in snow island and low island}

\subsubsection{Low island: the cape wallace beds}

The new U-Pb zircon age of $153.1 \pm 1.9$ Ma obtained for the Punta Ocoa Member constrains deposition of the upper part of the Anchorage Formation of the Byers Group to Kimmeridgian. This reinforces and reaffirms the Kimmeridgian-Tithonian biostratigraphic age for the formation based on molluscan fauna (Smellie et al. 1980; Pirrie and Crame 1995). Although with the exception of the fossil record (Thomson 1982), there is no new chronological control for the turbidite sequence of the Pencil Beach Member of the Cape Wallace Beds, this is the oldest identified unit on Low Island and it has a similar lithostratigraphy to the Anchorage Formation. We suggest a common age and similar depositional setting for these two sequences during the Late Jurassic. 
The new age U-Pb zircon age obtained for the Cape Wallace pluton, $137.1 \pm 1.7 \mathrm{Ma}$, is indistinguishable from that of the Hespérides Point intrusive of Hurd Peninsula, Livingston Island (138 $\pm 1 \mathrm{Ma}$; Hervé et al. 2006), which lies in a rather similar trenchward position relatively to the present-day continental margin. These are the oldest plutonic rocks known from the South Shetland Islands and, considering their geographical separation, they may represent a Valanginian intrusive pulse that occurred throughout the South Shetland Islands archipelago.

The U-Pb age (sample AASW-P1) was obtained from an ash-layer located towards the upper levels of the sequence in President Head Peninsula. The sample yielded $109.0 \pm 1.4 \mathrm{Ma}$, which constrains the age to the Aptian-Albian period.

The ${ }^{40} \mathrm{Ar} /{ }^{39} \mathrm{Ar}$ age of the Albatross Hill (Low Island) andesites is also Valanginian, ca. 136-138 Ma (see above). Since this unit is intruded by the Cape Wallace pluton, it would appear that the time interval between them was very short so that andesite volcanism and granodiorite plutonism were penecontemporaneous. Discounting a less precise ${ }^{40} \mathrm{Ar} /{ }^{39} \mathrm{Ar}$ age of $143 \pm 5 \mathrm{Ma}$ for basalt from western Livingston Island (Gracanin 1983), the Albatross Hill Member andesites are the oldest volcanic rocks in the South Shetland Islands. As noted above Haase et al. (2012) dated the mafic groundmass of lava from the Start Hill Formation of the Byers Group, yielding a ${ }^{40} \mathrm{Ar} /{ }^{39} \mathrm{Ar}$ age of $135 \pm 3$ $\mathrm{Ma}$, which also corresponds to Valanginian. Thus, the Albatross Hill Member of the Cape Wallace Beds could be correlated with the Start Hill Formation, suggesting extensive development of the Valanginian arc in the South Shetland Islands.

The gentle angular discordance between Pencil Beach and Albatross Hill members in Low Island and Anchorage with President Beach formations in Livingston islands seems to correspond to an erosional hiatus of ca. $12 \mathrm{Ma}$ (ca. 152-140 Ma, TithonianBerriasian). This might be related to tectonic uplift, probably due to the initiation of the subduction and subsequent volcanism recorded in the Albatross Hill Member and in Start Hill Formation.

A Valanginian volcanic belt in the archipelago would have implications for regional tectonic evolution. Some authors have identified a trend of progressively northeast decreasing age for the volcanism in the South Shetland Islands (Pankhurst and Smellie 1983; Smellie et al. 1984), which was supported by the regional study of Haase et al. (2012). Accordingly, the oldest volcanism should be exposed in the southwest, i.e. close to Low Island, so that the Valanginian volcanics rocks recorded in the Albatross Hill Member and the roughly coeval volcanism of the Start Hill Formation are consistent with this southwest-northeast younging trend.

\subsubsection{President head, snow island}

Possible correlation between the geology of President Head at Snow Island and the Byers Group was first suggested by Crame et al. (1993), based on its litho-, bio- and tectono-stratigraphic similarities. Torres et al. (1997), Hathway and Lomas (1998), and Israel (2015) proposed that the marine, ammonite-bearing, sedimentary succession dominated by greyish mudstones and sandstones outcropping at the western area could be equivalent to the Sealer Hill Member of the Chester Cone Formation. According to the marine invertebrates, in Snow Island might correspond to the midValanginian (Ugalde et al. 2013; Israel 2015).

Plant remains found in the volcaniclastic continental rocks at the top of the Snow Island succession show the emersion of the arc (Torres et al. 1997; Cantrill 1998; Hathway and Lomas 1998) and suggest a possible correlation with the Cerro Negro Formation (Cantrill 1998). Furthermore, the U-Pb zircon age of the sample AASWP1 (Figure 3) yields an age of $109 \pm 1$ Ma for an ash-layer near the base of this succession that constrains its age to Aptian-Albian, roughly coeval with the Cerro Negro Formation (Hathway et al. 1999). Israel (2015) also suggested that the age difference between the outcropping units on Snow Island corresponds to a ValanginianBarremian erosive period, which is also recorded in the Byers Group between the Start Hill and Cerro Negro formations (e.g., Hathway and Lomas 1998).

\subsection{Tectonic evolution of the byers basin}

We consider that the Byers Basin includes: i) the Upper Jurassic-Lower Cretaceous deposits of Byers Peninsula at the west of Livingston Island, ii) the Lower Cretaceous succession at President Head Peninsula at the northeast of Snow Island, and iii) the Upper Jurassic--Lower Cretaceous sequence at Cape Wallace, northwestern Low Island (Figure 3). These deposits define the Byers Basin, whose litho-stratigraphic evolution has two major stages: i) a deep-marine forearc environment during the Late Jurassic, ii) an Early Cretaceous volcanic/volcaniclastic arc-related sequence.

\subsubsection{Deep-marine sedimentation: upper jurassic}

The oldest units on Low and Livingston islands are deep-marine turbidite-like rocks deposited in a forearc setting: i) the Pencil Beach Member in Low Island, ii) the Anchorage Formation and the President Beaches Formation in Livingston Island. They are composed of mudstones and fine sandstones interbedded with 
minor ash-layers (e.g. Bastias, 2014; Hathway and Lomas 1998). The fossil record shows an Oxfordian affinity on Low Island (Thomson 1982; Kiessling et al. 1999) and Kimmeridgian-Berriasian ages on Livingston Island (Smellie et al. 1980; Pirrie and Crame 1995). Our U-Pb data provide a constraint of Kimmeridgian depositional age $(153.1 \pm 1.7 \mathrm{Ma})$ for an ash-layer in the Anchorage Formation.

\subsubsection{Shallower sedimentation and volcanic activity: lower cretaceous}

The upper part of the Byers basin features transition to shallower water deposits and erosional hiatus. The youngest deposits of the Byers Basin consist of volcanovolcaniclastic rocks of continental affinity recorded by abundant paleobotanic fauna.

The Lower Cretaceous units in the Byers Group comprise: i) shallower water sedimentation of the midto-late Berriasian President Beaches Formation, ii) the volcanic rocks of the Start Hill Formation, iii) the slopeapron sandstones of the President Beaches Formation and iv) the shallower-marine conglomerates and mudstones of the Chester Cone Formation. Although the deposits of the Chester Cone Formation may indicate paucity of igneous activity in the arc or a transgression, the sequence at Byers Peninsula represents a continuous marine regression from shallowermarine from the Berriasian (President Beaches Formation) to subaerial basaltic lavas in the Valanginian-Hauterivian (Start Hill Formation). This tendency is extended in the sequence recorded in President Head at Snow Island, which records deposits of volcanic and volcaniclastic continental, low-energy sediments, conglomerates and tuffs. On Low Island, the Lower Cretaceous features abundant volcanic and volcaniclastic products of Valanginian age at ca. 139-137 Ma (Figure 6).

\subsection{Mesozoic fore- and intra-arc deposits of adelaide island and alexander island}

Mesozoic fore-arc units are also exposed further south of the South Shetland Islands, in Adelaide Island (e.g. Riley et al. 2012, Figure 1) and Alexander Island (e.g. Butterworth et al. 1988, Figure 1). Below we review the similarities and differences of these deposits relative to those of the Byers Basin.

\subsubsection{Adelaide island}

Adelaide Island lies off the west coast of Antarctic Peninsula, $150 \mathrm{~km}$ south of Low Island (Figure 1). Riley et al. (2012) revised the Mesozoic-early Cenozoic lithostratigraphy of Adelaide Island on the basis of geological mapping and U-Pb geochronology. Fore-arc deposits form a succession of $2-3 \mathrm{~km}$ of coarse turbiditic sandstones and volcanic rocks, divided into five formations (Riley et al. 2012). We will focus on the two oldest formations of the sequence, which span the Late Jurassic-Early Cretaceous period of the Byers Basin. At the base of the sequence is the Buchia Buttress Formation, $\sim 400 \mathrm{~m}$ of breccias, tuffs, volcaniclastic rocks and minor sandstones. Marine fossils suggest a Tithonian age (Thomson 1972), confirmed by $\mathrm{U}-\mathrm{Pb}$ (zircon) dating of a crystal tuff at $149.5 \pm 1.6$ Ma (Riley et al. 2012). The overlying Milestone Bluff Formation was deposited during Aptian-Albian time. It is composed of subaerial volcaniclastic and volcanic rocks dominated by conglomerates and sandstones and minor interbedded silicic tuff date at $113.9 \pm 1.2 \mathrm{Ma}$ (Riley et al. 2012). These deposits are overlain by dominantly volcanic formations that record activity until at least the Late Cretaceous (Riley et al. 2012).

Deposition in Adelaide Island, as the Byers Basin, records a transition from deep-marine sedimentation during the Late Jurassic towards shallower deposits and volcanic activity during the Cretaceous. Thus, the overall pattern broadly coincides in chronology and lithology, although direct correlation between these units is not possible due to either lack chronological control or a different depositional regime at the latitude of Alexander Island.

\subsubsection{Alexander island: fossil bluff group}

Alexander Island is located a further $300 \mathrm{~km}$ to the south of Adelaide Island (Figure 1) and is the largest island off the west coast of the Antarctic Peninsula. The Fossil Bluff Group crops out as a $250 \mathrm{~km}$ long and $30 \mathrm{~km}$ wide belt on the eastern side of the island. This is a continuous Middle Jurassic-Lower Cretaceous volcano-sedimentary sequence about $7 \mathrm{~km}$ thick (Butterworth et al. 1988; Doubleday et al. 1993; Riley et al. 2012). The sequence has been divided into seven formations (Doubleday and Storey 1998). Two major stages have been identified (Riley et al. 2012): i) a first stage recording a transition from trench-slope deposits to fore-arc sedimentation and ii) a second stage representing upward shallowing of the fore-arc to intra-arc basin deposits. The first stage is exposed in the Atoll Nunataks and Selene Nunatak formations, composed of mainly volcaniclastic sandstone and conglomerate derived from a volcanic arc (Doubleday et al. 1993). Its age is poorly constrained by scarce fossil content that has suggested a Middle-Late Jurassic age (Butterworth et al. 1988; Doubleday et al. 1993). The later formations 
are part of the second stage and are composed of mainly shelf mudstones and sandstones, with sedimentation ages spanning Kimmeridgian (Upper Jurassic) to Albian (Lower Cretaceous), based mostly on fossil studies (Butterworth et al. 1988; Butterworth and Macdonald 1991).

Riley et al. (2012) presented a detailed chronostratigraphic and lithostratigraphic revision of the MesozoicPaleogene fore-arc units in Adelaide and Alexander Island supported by U-Pb zircon dating. They proposed a tentative correlation between the Fossil Bluff Group and the fore-arc units of Adelaide Island. In particular, they correlated the Himalia Ridge Formation (Alexander Island) with the Buchia Buttress Formation and, tentatively, the Pluto Glacier Formation with the sandstoneconglomerate-dominated succession of the Milestone Bluff Formation.

Thus, the possible correlations suggested above between the Byers Basin and the Mesozoic fore-arc units in Adelaide Island could be also extended to the succession on Alexander Island, based on the correlations proposed by Riley et al. (2012) (Figures 7 and 8). Precise correlation is not possible given the lack of more detailed time constraints, but in a broad sense and from a regional perspective, the depositional regime that contributes to the formation of the Byers Basin might have extended to the latitude of Adelaide and Alexander islands.

\subsection{The relationship of the Byers Basin to the Larsen Basin: the fore- and back-arc evolution of Antarctic Peninsula}

The idea of correlating the Jurassic-Cretaceous sequences across the eastern flank of the Antarctic Peninsula has been explored (Del Valle et al. 1992; Hathway 2000). He defined the Larsen Basin comprising rift deposits that evolved into back-arc sequences. The succession exhibits four major stages: i) Middle Jurassic non-marine sedimentary and volcanic rocks that are interpreted as a syn-rift sequence, recording initial largely non-magmatic extension and subsequent silicic volcanism; ii) a late Upper Jurassic-early Lower Cretaceous succession of marine hemipelagic mudstones and sandstones; iii) a Lower Cretaceous sequence of deep-marine fan of slope-apron deposits to the east, coeval with emergence of the arc to the west; and iv) Upper Cretaceous shallow marine deposits in a broadly regressive sequence with transgressive episodes (Olivero 2012).

The sedimentation stages of the Larsen Basin described by Hathway (2000) combined with the correlations here explored for the Byers Basin may represent a synchronous evolution of what later become back-arc and fore-arc deposits of the Antarctic Peninsula, respectively. These stages are presented in Figure 9:

- During Middle-Late Jurassic time the area seems to have been largely submerged under water (Figure

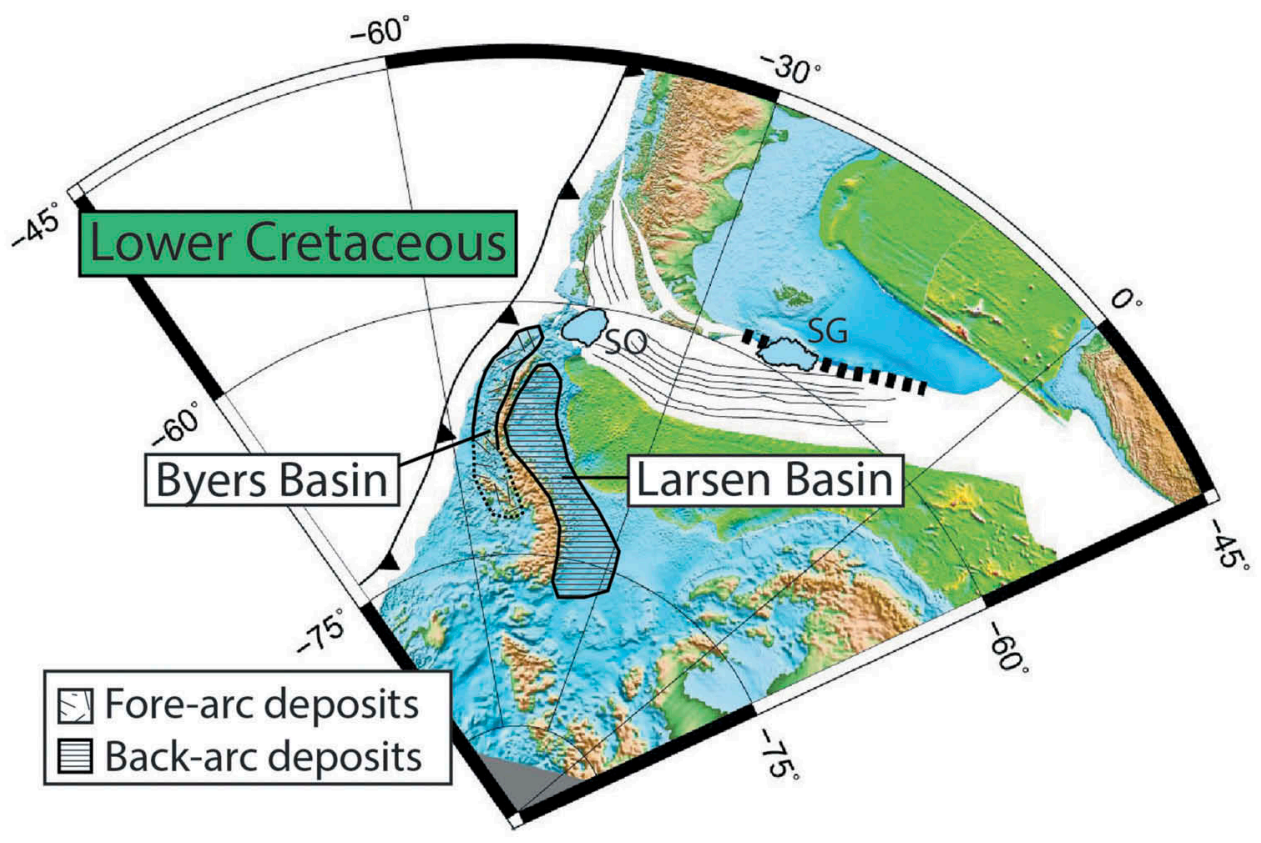

Figure 7. Late Cretaceous plate reconstruction for Antarctic Peninsula and Patagonia from Poblete et al. (2016) showing the potential location and extension of the fore-arc deposits of the Byers Basin, back-arc of Larsen Basin. SO and SG correspond, respectively, to South Orkney and South Georgia islands. Dashed lines in the Byers Basin correspond to the potential lithostratigraphical correlation of the Mesozoic fore-arc deposits in the South Shetlands Islands with the fore-arc units described by Riley et al. (2012) in Adelaide and Alexander islands. 


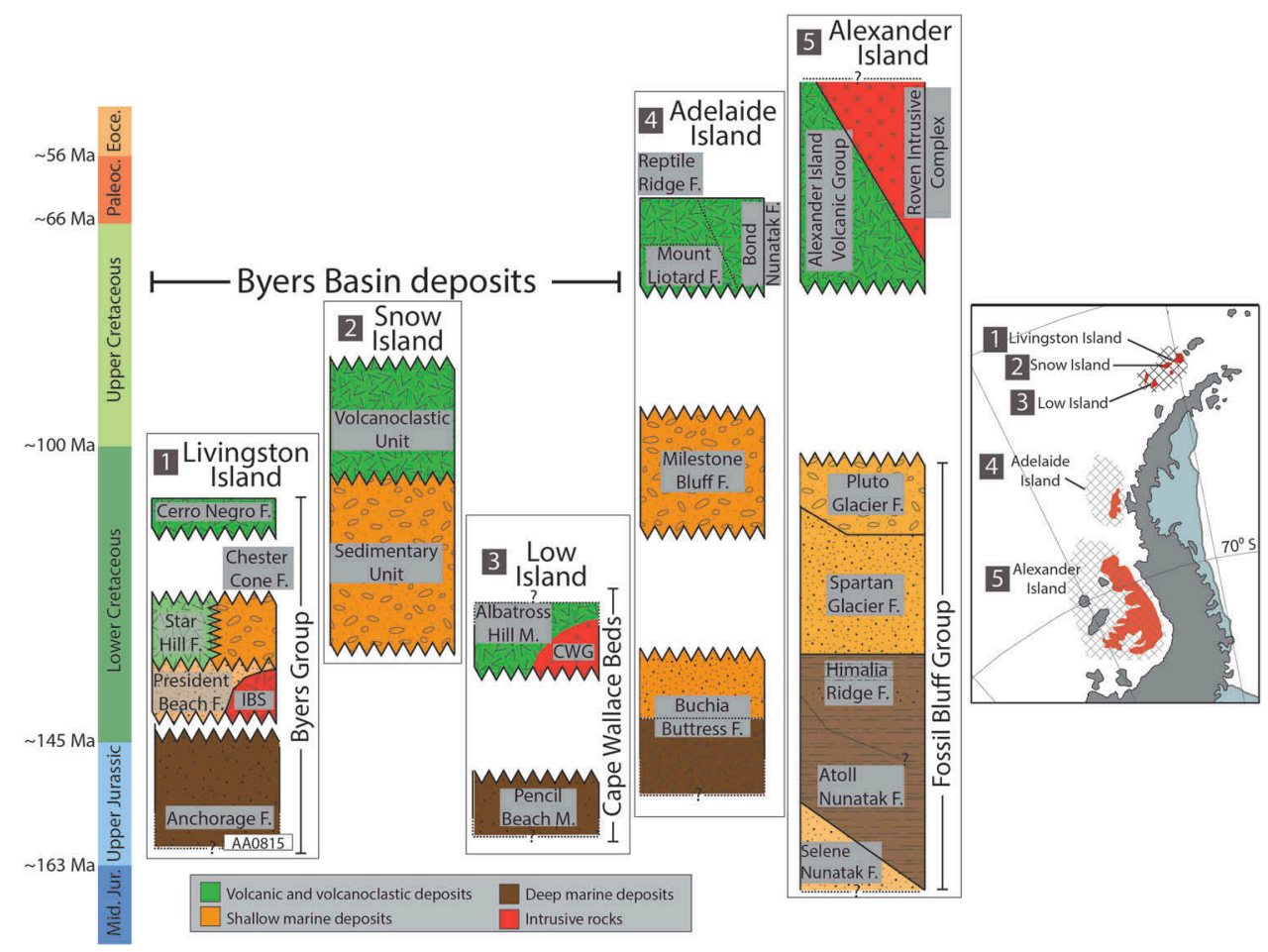

Figure 8. Schematic comparative stratigraphy of the fore-arc deposits here considered with its locations in Antarctic Peninsula. North to south are: the Byers Group of Livingston Island (from Hathway and Lomas 1998, Kiessling et al., 1999); Snow Island (from Israel Israel 2015); Cape Wallace Beds of Low Island (from Bastias, 2014); Adelaide Island (from Riley et al. 2012) and the Fossil Group of Alexander Island (from Storey et al. 1996).

9(a)), with deep-marine deposits recorded both in the west (Anchorage Formation in Livingston Island, Pencil Beach Member in Low Island and Buchia Buttress Formation in Adelaide Island, Himalia Ridge Formation in Alexander Island).

- During the Late Jurassic and Early Cretaceous in the west continental and shallow marine deposits were formed, indicating the start of a significant marine regression cycle (Figure 9(b)) (President Beaches and Chester Cone formations in Livingston Island, Buchia Buttress Formation in Adelaide Island and Himalia Ridge Formation in Alexander Island). At the same period, the eastern area was dominated by hemipelagic marine sedimentation, which marks the initiation of the marine transgression cycle (Nordenskjöld Formation).

- In the Early Cretaceous, the west was dominated by volcanic and shallow deposits enhancing the regression cycle (Figure 9(c)) (President Beach and Start Hill formations in Livingston Island, Albatross Hill Member in Low Island, Milestone Bluff Formation in Adelaide Island and Spartan Glacier Formation in Alexander (sland). The east was at this time characterized by deep-marine deposits which marks the last stage of the transgression cycle (Kotick Point and Pedersen Formation).
- Finally, the Late Cretaceous is marked by regressions at both flanks of the peninsula (Figure 9(d)). While the west is marked by aerial and sub-aerial volcanic deposits (Cerro Negro Formation in Livingston Island; Mount Liotard, Reptile Ridge and Bond Nunatak formations in Adelaide Island and the Alexander Island Volcanic Group) the east is marked by shallower marine deposits (Gustav and Marambio groups). These deposits also show the definitive emergence of the arc in the Antarctic Peninsula.

\subsection{Implications for the mesozoic evolution of the antarctic peninsula}

Vaughan and Storey (2000), suggested that the Antarctic Peninsula was composed of allochthonous blocks (Western and Central domains) that collided with a pre-existing Gondwana block (Eastern Domain), at about 105 Ma (Vaughan et al. 2002) or during the Late Triassic (Vaughan et al., 2012).

According to this model, the rocks of the Byers Basin would be part of the Western and Central domains and the rocks of the Larsen Basin to the Eastern Domain. However, the coupled evolution of the Byers Basin (Western Domain) and the Larsen Basin (Eastern 

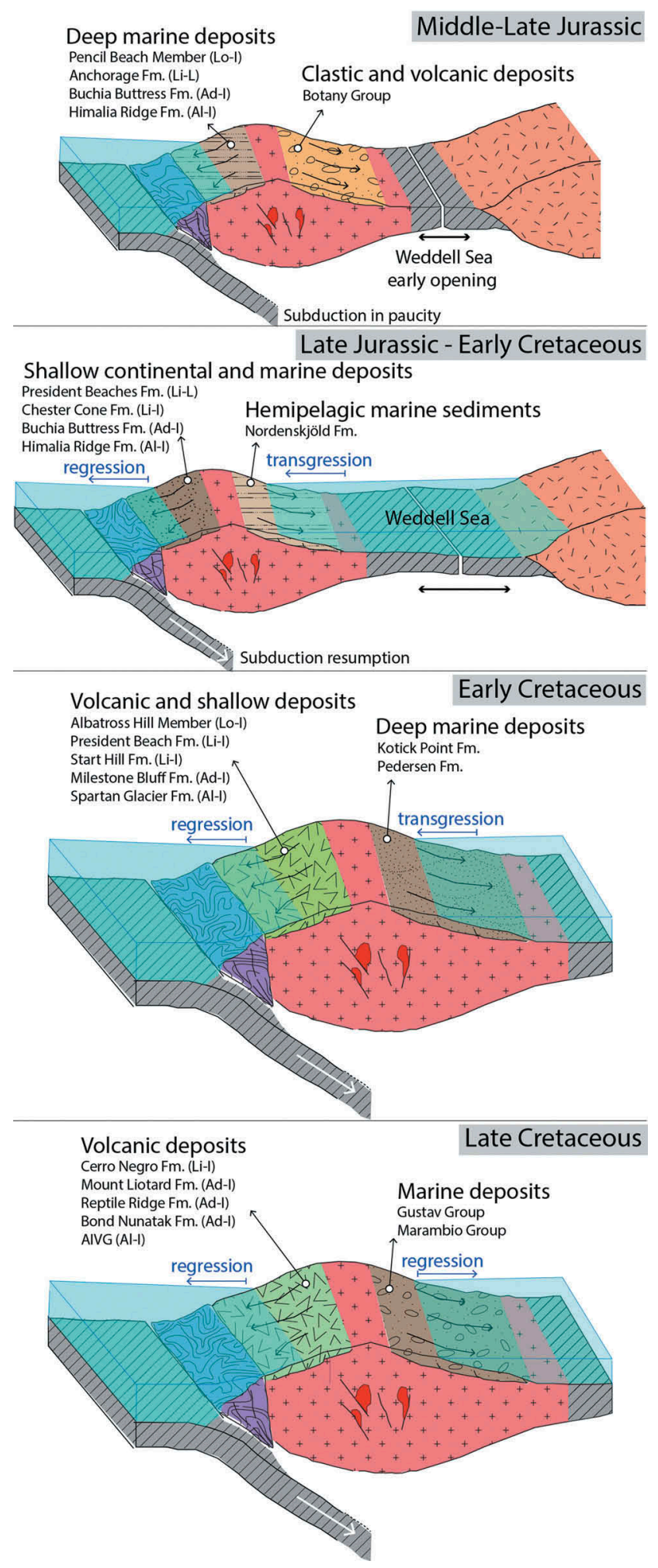

Figure 9. Sequential schematic block diagrams showing the potential coeval evolution of the Antarctic Peninsula of the Larsen Basin from a back-arc to a foreland basin and the Byers Basin from a fore- to an intra-arc basin. Middle-Late Jurassic, Late Jurassic - Early Cretaceous, Early Cretaceous and Late Cretaceous. Lo-I, Low Island; Li-L, Livingston Island; Ad-I Adelaide Island; Al-I, Alexander Island.
Domain) during Late Jurassic and Cretaceous times suggests that these regions probably were part of the same crustal block, and thus not directly supporting the allochthonous. Further, our data better support the model considering an active margin setting since the Permian - Triassic period (Burton-Johnson and Riley 2015; Bastias et al. 2019).

\section{Conclusions}

Local conclusions:

(1) Together with the age reported in Hurd Peninsula, Livingston Island (137.7 $\pm 1.4 \mathrm{Ma}$; Hervé et al. 2006) the crystallization age of the Cape Wallace Pluton of $137.9 \pm 1.7 \mathrm{Ma}$ is the oldest age of a plutonic rock in the South Shetland Islands. This suggests an extended Valanginian (Lower Cretaceous) magmatic belt may be present in the South Shetland Islands.

(2) The ${ }^{40} \mathrm{Ar} /{ }^{39} \mathrm{Ar}$ plateau ages of the Albatross Hill Member in Low Island are the oldest record of volcanism in the South Shetland Islands (139.7 \pm 0.3 to $137.5 \pm 0.7 \mathrm{Ma}$ ). This is in agreement with the trend of decreasing ages from southwest to northeast, which that predicts the older ages in the position of Low Island. However, the emplacement ages of the Start Hill Formation in Livingston Island of ca. 135 Ma might not be significantly younger given the distance that separates these islands. Further, it may suggest that the South Shetland Islands record a belt of Valanginian volcanism, which does not support the proposed decreasing age as a regional trend.

Regional conclusions:

(1) The Byers Basin as defined here, comprises the Cape Wallace Beds of Low Island, the Byers Group of Livingston Island and the President Head deposits of Snow Island. These volcanosedimentary sequences show an evolution from: i) Upper Jurassic deep-marine turbidite-like sequences deposited in a fore-arc setting, and ii) volcanic deposits of basic to andesite composition deposited during the Early Cretaceous in an intra-arc setting that records the first volcanic products of subduction.

(2) Following correlations proposed by Riley et al. (2012) linking the fore-arc deposits of Alexander Island with Adelaide Island, and comparison of 
these with the Byers Basin, it is possible to consider that the tectonic environment of Byers Basin deposition possibly extended along a significant portion of the western flank of the Antarctic Peninsula as far as the latitudes of Adelaide and Alexander islands.

(3) The lithostratigraphical evolution of the back-arc to foreland Larsen Basin on the eastern flank of the Antarctic Peninsula together with the fore-arc to intra-arc evolution of the Byers Basin may define coupled evolution within the same crustal block.

(4) These correlations imply a major co-evolutionary feature in the northern Antarctic Peninsula and suggest that, at least in the northern Antarctic Peninsula, a terrane model for the Antarctic Peninsula might not apply during the Late Cretaceous.

\section{Acknowledgments}

The authors are grateful for the extensive logistical support provided by the Chilean Antarctic Institute (INACH) during two field campaigns to the Antarctic Peninsula. The manuscript was greatly improved by the input of the reviewers Dr. Liang Gao and Dr Eduardo Olviero. We are grateful for Dr. Alfonso Rubilar (SERNAGEOMIN) for the review of fossil specimens. Financial support was provided by the Antarctic Ring Project (ACT-105, Conicyt-Chile and INACH), the project RT0614 (INACH) and the Fondecyt Grant 1161818.

\section{Disclosure statement}

No potential conflict of interest was reported by the authors.

\section{ORCID}

Joaquin Bastias (D) http://orcid.org/0000-0001-6678-3173

\section{References}

Araya, R., and Hervé, F., 1966, Estudio geomorfológico y geológico en las Islas Shetland del Sur, Antártica: Publicaciones Instituto Antártico Chileno, v. 8, p. 1-76.

Bastias, J. 2014. Mineralogía y geocronología U-Pb en las Islas Shetland del Sur, Antártica, un multienfoque para Punta Hannah, Isla Livingston y Cabo Wallace [Isla Low Ms Thesis Geology Department]: Santiago, Universidad de Chile. http://www.repositorio.uchile.cl/handle/2250/115611

Bastias, J., Fuentes, F., Aguirre, L., Hervé, F., Demant, A., Deckart, K., and Torres, T., 2016, Very low-grade secondary minerals as indicators of palaeo-hydrothermal systems in the Upper Cretaceous volcanic succession of Hannah Point, Livingston Island, Antarctica: Applied Clay Science, v. 134,p. 246-256. doi:10.1016/j.clay.2016.07.025.

Bastias, J., and Hervé, F., 2013, The Cape Wallace Beds: a Permian-detritus turbidite unit at Low Island, South
Shetland Islands: Bollettino Di Geofisica Teorica Ed Applicata, v. 54, no. Supplement 2, p. 312-314.

Bastias, J., Spikings, R., Ulianov, A., Riley, T., Burton-Johnson, A., Chiaradia, M., Baumgartner, L., and Hervé, F., 2019, The gondwanan margin in West Antarctica: Insights from Late Triassic Magmatism of the Antarctic Peninsula: EarthArXiv, doi:10.31223/osf.io/8ds42.

Black, L.P., Kamo, S.L., Allen, C.M., Aleinikoff, J.N., Davis, D.W., Korsch, R.J., and Foudoulis, C., 2003, TEMORA 1: a new zircon standard for Phanerozoic U-Pb geochronology: Chemical Geology, v. 200, p. 155-170. doi:10.1016/S00092541(03)00165-7.

Burton-Johnson, A., and Riley, T.R., 2015, Autochthonous v. accreted terrane development of continental margins: a revised in situ tectonic history of the Antarctic Peninsula: Journal of the Geological Society of London, doi:10.1144/jgs2014-1110.

Butterworth, P.J., and Macdonald, D.I.M., 1991, Basin shallowing from the Mesozoic Fossil Bluff Group of Alexander Island and its regional tectonic significance, in Thomson, M.R.A., Crame, J.A., and Thomson, J.W., eds., Geological Evolution of Antarctica: Cambridge, Cambridge University Press, p. 449-453.

Butterworth, P.J., Crame, J.A., Howlett, P.J., and Macdonald, D.I.M., 1988, Lithostratigraphy of Upper Jurassic-Lower Cretaceous strata of eastern Alexander Island, Antarctica: Cretaceous Research, v. 9, p. 249-264. doi:10.1016/0195-6671(88)90020-1.

Cantrill, D.J., 1998, Early Cretaceous fern foliage from President Head, Snow Island, Antarctica: Alcheringa, v. 22, no. 3, p. 241-258, doi:10.1080/03115519808619203.

Cantrill, D.J., 2000, A Cretaceous (Aptian) flora from President Head, Snow Island, Antarctica: Palaeontographica, v. 253, p. 153-191. doi:10.1127/palb/253/2000/153.

Castillo, P., Lacassie, J.P., Augustsson, C., and Hervé, F., 2015, Petrography and geochemistry of the Carboniferous-Triassic Trinity Peninsula Group, West Antarctica: implications for provenance and tectonic setting: Geological Magazine, v. 152, p. 575-588. doi:10.1017/S0016756814000454.

Covacevich, C.V., 1976, Fauna Valanginiana de Península Byers, Isla Livingston, AntaÂrtica: Revista Geoloâgica De Chile, v. 3, p. 25-56.

Crame, J.A., 1984, Preliminary bivalve zonation of the JurassicCretaceous boundary in Antarctica, in Perilliat, M.C., ed., Memoria III Congreso Latino-americano de Paleontología, México 1984: Mexico City, Universidad Nacional Autónoma de México, Instituto de Geología, p. 242-254.

Crame, J.A., Pirrie, D., Crampton, J.S., and Duane, A.M., 1993, Stratigraphy and regional significance of the Upper Jurassic-Lower Cretaceous Byers Group, Livingston Island, Antarctica: Journal of the Geological Society, London, v. 150, p. 1075-1087. doi:10.1144/gsjgs.150.6.1075.

Del Valle, R.A., Elliot, D.H., and Macdonald, D.I.M., 1992, Sedimentary basins on the east fank of the Antarctic Peninsula: proposed nomenclature: Antarctic Science, v. 4, p. 477-478. doi:10.1017/S0954102092000695.

Doubleday, P.A., Macdonald, D.I.M., and Nell, P.A.R., 1993, Sedimentology and structure of the trench-slope to forearc basin transition in the Mesozoic of Alexander Island, Antarctica: Geological Magazine, v. 130, p. 737-754. doi:10.1017/S0016756800023128. 
Doubleday, P.A., and Storey, B.C., 1998, Deformation history of a Mesozoic forearc basin sequence on Alexander Island, Antarctic Peninsula: Journal of South American Earth Sciences, v. 11, p. 1-21. doi:10.1016/S0895-9811(97)00032-1.

Duane, A.M., 1994, Preliminary palynological investigations of the Byers Group (Late Jurassic-Early Cretaceous), Livingston Island, Antarctic Peninsula: Review of Palaeobotany and Palynology, v. 84, p. 113-120. doi:10.1016/0034-6667(94) 90045-0.

Duane, A.M., 1996, Palynology of the Byers Group (Late Jurassic-Early Cretaceous) of Livingston and Snow Islands, Antarctic Peninsula: its biostratigraphical and palaeoenvironmental significance: Review of Palaeobotany and Palynology, v. 91, p. 241-281. doi:10.1016/0034-6667(95) 00094-1.

Falcon-Lang, H.J., and Cantrill, D.J., 2001, Gymnosperm woods from the Cretaceous (mid-Aptian) Cerro Negro Formation, Byers Peninsula, Livingston Island, Antarctica: the arborescent vegetation of a volcan: Cretaceous Research, v. 22, p. 277-293. doi:10.1006/cres.2001.0259.

Gracanin, T.M. 1983. Geochemistry and geochronology of some Mesozoic igneous rocks from the northern Antarctic Peninsula region [M.Sc. Thesis]: Ohio State University

Haase, K.M., Beier, C., Fretzdorff, S., Smellie, J.L., and GarbeSchönberg, D., 2012, Magmatic evolution of the South Shetland Islands, Antarctica, and implications for continental crust formation: Contributions to Mineralogy and Petrology, v. 163, p. 1103-1119. doi:10.1007/s00410-0120719-7.

Hathway, B., 1997, Nonmarine sedimentation in an Early Cretaceous extensional continental-margin arc, Byers Peninsula, Livingston Island, South Shetland Islands: Journal of Sedimentary Research, v. 67, p. 686-697. doi:10.1306/D4268617-2B26-11D7-8648000102C1865D.

Hathway, B., 2000, Continental rift to back-arc basin: JurassicCretaceous stratigraphical and structural evolution of the Larsen Basin, Antarctic Peninsula: Journal of the Geological Society, London, v. 157, p. 417-432. doi:10.1144/ jgs.157.2.417.

Hathway, B., Duane, A.M., Cantrill, D.J., and Kelley, S.P., 1999, ${ }^{40} \mathrm{Ar} /{ }^{39} \mathrm{Ar}$ geochronology and palynology of the Cerro Negro Formation, South Shetland Islands, Antarctica: a new radiometric tie for Cretaceous terrestrial biostratigraphy in the Southern Hemisphere: Australian Journal of Earth Sciences, v. 46, no. 4, p. 593-606, doi:10.1046/ j.1440-0952.1999.00727.x.

Hathway, B., and Lomas, S.A., 1998, The Upper Jurassic-Lower Cretaceous Byers Group, South Shetland Islands, Antarctica: revised stratigraphy and regional correlations: Cretaceous Research, v. 19, p. 43-67. doi:10.1006/cres.1997.0095.

Hervé, F., Faúndez, V., Brix, M., and Fanning, M., 2006, Jurassic sedimentation of the Miers Bluff Formation, Livingston Island, Antarctica: evidence from SHRIMP U-Pb ages of detrital and plutonic zircons: Antarctic Science, v. 18, p. 229-238. doi:10.1017/S0954102006000277.

Israel, L., 2015, Geología de President Head, isla Snow, archipiélago del Sur, Antártica: Santiago, Geology Department, Universidad de Chile, http://repositorio. uchile.cl/handle/2250/137605

Kiessling, W., 1999, Late jurassic radiolarians from the antarctic peninsula: micropaleontology, v. 45, no. 1, p. 1-96.
Kniper, K., Deino, A., Hilgen, F., Krijgsman, W., Renne, P., and Wijbrans, J.R., 2008, Synchronizing Rock Clocks of Earth History: Science, v. 320, p. 500-504. doi:10.1126/ science. 1154339.

König, M., and Jokat, W., 2006, The Mesozoic breakup of the Weddell Sea: Journal of Geophysical Research 111B12102, 1-28, doi:10.1029/2005JB004035.

Koppers, A.A.P., 2002, ArArCALC-software for 40Ar/39Ar age calculations: Computers and Geosciences, v. 28, p. 605-619. doi:10.1016/S0098-3004(01)00095-4.

Lanphere, M.A., and Dalrymple, G.B. 1978. The use of ${ }^{40} \mathrm{Ar} /{ }^{39} \mathrm{Ar}$ data in evaluation of disturbed K-Ar systems, Geological Survey Open-file Report 78-701, U.S, pp. 241-243.

Leat, P.T., Scarrow, J.H., and Millar, I.L. 1995. On the Antarctic Peninsula batholith: Geological Magazine, v. 132, p. 399-412. doi:10.1017/S0016756800021464.

Leppe, M., Michea, W., Muñoz, C., Palma-Heldt, S., and Fernandoy, F., 2007, Paleobotany of Livingston Island: the first report of a Cretaceous fossil flora from Hannah Point, in Cooper, A.K., and Raymond, C.R., et al., eds., Antarctica: A Keystone in a Changing World. The National Academies Press, Santa Barbara, California, U.S.A., pp. 1-4. doi:10.3133/of2007-1047.srp081.

Lomas, S.A., 1999, A Lower Cretaceous clastic slope succession, Livingston Island, Antarctica: sand-body characteristics, depositional processes and implications for slope apron depositional models: Sedimentology, v. 46, p. 477-504. doi:10.1046/j.1365-3091.1999.00225.x.

Ludwig, K.R., 2001, SQUID 1.02, A user's manual: Berkeley Geochronology Center, Special, Publication 2. https://scholar.google.ch/scholar?hl=es\&as_sdt $=0 \%$

2C5\&as_vis=1\&q=Ludwig\%2C+2001\%2C+SQUID+1.02\%2C + A+user\%E2\%80\%99s+manual\&btnG $=$.

Ludwig, K.R., 2003, Isoplot/Ex version 3.00. A Geochronological Toolkit for Microsoft Excel, User's Manual: Berkeley Geochronology Center Special Publications, v. 4, p. 1-70.

Olivero, E.B., 2012, Sedimentary cycles, ammonite diversity and palaeoenvironmental changes in the Upper Cretaceous Marambio Group, Antarctica: Cretaceous Research, v. 34, p. 348-366. doi:10.1016/j. cretres.2011.11.015.

Pankhurst, R.J., 1982, Rb-Sr geochronology of Graham Land, Antarctica: Journal of the Geological Society, v. 139, p. 701-711. doi:10.1144/gsjgs.139.6.0701.

Pankhurst, R.J., Riley, T.R., Fanning, C.M., and Kelley, S.P., 2000, Episodic silicic volcanism in Patagonia and the Antarctic Peninsula: chronology of magmatism associated with the breakup of Gondwana: Journal of Petrology, v. 41, p. 603-625. doi:10.1093/petrology/41.5.605.

Pankhurst, R.J., and Smellie, J.L., 1983, K-Ar geochronology of the South Shetland Islands, Lesser Antartica: apparent lateral migration of Jurassic to Quaternary island arc volcanism: Earth Planetary Sciences Letters, v. 66, p. 214-222. doi:10.1016/0012-821X(83)90137-1.

Pankhurst, R.J., Weaver, S.D., Brook, M., and Saunders, A.D., 1979, K-Ar chronology of Byers Peninsula, Livingston Island, South Shetland Islands: British Antarctic Survey Bulletin, v. 49, p. 277-282.

Philippe, M., Torres, T., Barale, G., and Thevenard, F., 1995, President Head, Snow Island, South Shetland, a key point 
for Antarctic Mesozoic palaeobotany: Comptes rendus de I'Académie des Sciences, Paris, Series II 321, 1055-1061.

Pirrie, D., and Crame, J.A., 1995, Late Jurassic palaeogeography and anaerobic-dysaerobic sedimentation in the northern Antarctic Peninsula región: Journal of the Geological Society, v. 152, p. 469-480. doi:10.1144/gsjgs.152.3.0469.

Poblete, F., Roperch, P., Arriagada, C., Ruffet, G., Ramírez de Arellano, C., Herve, F., and Poujol, M., 2016, Late cretaceouseearly eocene counterclockwise rotation of the fueguian Andes and evolution of the PatagoniaeAntarctic Peninsula system: Tectonophysics, v. 668e669,p. 15e34. doi:10.1016/j. tecto.2015.11.025.

Riley, T.R., Flowerdew, M.J., and Whitehouse, M.J., 2012, Chrono- and lithostratigraphy of a Mesozoic-Tertiary foreto intra-arc basin: Adelaide Island, Antarctic Peninsula: Geological Magazine, v. 149, p. 768-782. doi:10.1017/ S0016756811001002.

Riley, T.R., Leat, P.T., Pankhurst, R.J., and Harris, C., 2001, Origins of large-volume rhyolite volcanism in the Antarctic Peninsula and Patagonia by crustal melting: Journal of Petrology, v. 42, p. 1043-1065. doi:10.1093/petrology/42.6.1043.

Smellie, J.L., 1979, The geology of Low Island, South Shetland Islands, and Austin Rocks: British Antarctic Survey, v. 49, p. 239-257.

Smellie, J.L., Davies, R.E., and Thomson, M.R., 1980, Geology of a Mesozoic intra-arc sequence on Byers Peninsula, Livingston Island, South Shetland islands: British Antarctic Survey Bulletin, v. 50, p. 55-76.

Smellie, J.L., Pankhurst, R.J., Thomson, M.R.A., and Davies, R.E. S. 1984. The geology of the South Shetland Islands: VI stratigraphy, geochemistry and evolution, British Antarctic Survey, Scientific Report, v. 87, p. 85.

Steiger, R.H., and Jager, E., 1977, Subcommission on geochronology: Convention on the use of decay constants in geoand cosmochronology: Earth and Planetary Science Letters, v. 36, p. 359-362. doi:10.1016/0012-821X(77)90060-7.

Storey, B., Vaughan, A., and Millar, I., 1996, Geodynamic evolution of the Antarctic Peninsula during Mesozoic times and its bearing on Weddell Sea history, in Storey, B., King, E., and Livermore, R., eds., Weddell Sea Tectonics and Gondwana Break-up. Geological Society volume Vol. 108: London, Special Publications, p. 87-103.

Thomson, M.R.A., 1972, New discoveries of fossils in the Upper Jurassic volcanic group of Adelaide Island: British Antarctic Survey Bulletin, v. 30, p. 95-101.

Thomson, M.R.A., 1982, Late Jurassic fossils from Low Island, South Shetland Islands: British Antarctic Survey Bulletin, v. 56, p. $25-35$.
Torres, T., Barale, G., Méon, H., Philippe, M., and Thévenard, F., 1997, Cretaceous floras from Snow Island (South Shetland Islands, Antarctica) and their biostratigraphic significance, in Ricci, C.A., ed., The Antarctic Region: Geological Evolution and Processes: Terra Antarctica Publication, Siena, p. 1023-1028.

Torres, T., Bastias, J.; Otero, R., and Calderon, M. 2015. Nuevos registros de Araucariáceas y Podocarpáceas del Cretácico Superior de Punta Hannah, Isla Livingston, Archipiélago de las Shetland del Sur, Antártica. 14 Congreso Geológico Chileno, La Serena, Chile, 4-8 October 2015, v. 3, 667-670.

Ugalde, R., Torres, T., Israel, L., Galleguillos, M., Hervé, F., and Fanning, C.M., 2013, New geological data and paleontological records of President Head Peninsula, Snow Island, South Shetland Islands, Antarctica: A key for the Lower Cretaceous: Bollettino Di Geofisica Teorica Et Aplicata, v. 54, p. 359.

Valenzuela Ayala, E., 1971, Geología de península Byers, isla Livingston, Antártica. Memoria de geólogo: Santiago, Universidad de Chile, Facultad de Ciencias Físicas y Matemáticas, p. 63.

Valenzuela, E., and Hervé, F., 1972, Geology of Byers Peninsula, Livingston Island, South Shetland Islands, in Adie, R.J., ed. Antarctic Geology and Geophysics: Oslo, Universitetsforlaget, p. 83-89.

Vaughan, A., and Storey, B., 2000, The eastern Palmer Land shear zone: A new terrane accretion model for the Mesozoic development of the Antarctic Peninsula: Journal of the Geological Society, London, v. 157, p. 1243-1256. doi:10.1144/jgs.157.6.1243.

Vaughan, A.P., Kelley, S.P., and Storey, B.C., 2002, MidCretaceous ductile deformation on the Eastern Palmer Land Shear Zone, Antarctica, and implications for timing of Mesozoic terrane collision: Geological Magazine, v. 139, p. 465-471. doi:10.1017/S0016756802006672.

Vaughan, A.P.M., Leat, P.T., Dean, A.A., and Millar, I.L. 2012. Crustal thickening along the west antarctic gondwana margin during mid-cretaceous deformation of the triassic intraoceanic dyer arc. Lithos, 142-143, 130- 147. doi:10.1016/j. lithos.2012.03.008.

Vermeesch, P., 2012, On the visualization of detrital age distributions: Chemical Geology, v. 312, no. 313, p. 190-194, doi:10.1016/j.chemgeo.2012.04.021.

Williams, I.S., 1998, U-Th-Pb geochronology by ion microprobe, in McKibben, M.A., Shanks, W.C., and Ridley, W.I., eds., Applications of microanalytical techniques to understanding mineralizing processes. Reviews in Economic Geology volume: Vol. 7: 1-35 p. 